\title{
Soil Moisture Responses Under Different Vegetation Types to Winter Rainfall Events in a Humid Karst Region
}

\section{Weihong Yan}

Guizhou Normal University

Qiuwen Zhou ( $\square$ zouqiuwen@163.com)

Guizhou Normal University

\section{Dawei Peng}

Guizhou Normal University

\section{Xiaocha Wei}

Guizhou Normal University

\section{Xin Tang}

Guizhou Normal University

\section{Ershuang Yuan}

Guizhou Normal University

\section{Yalin Wang}

Guizhou Normal University

Chunmao Shi

Guizhou Normal University

\section{Research Article}

Keywords: soil moisture, different vegetation types, winter rainfall events, response characteristics

Posted Date: February 16th, 2021

DOI: https://doi.org/10.21203/rs.3.rs-229406/v1

License: (c) (1) This work is licensed under a Creative Commons Attribution 4.0 International License. Read Full License 


\section{Soil Moisture Responses under Different Vegetation Types to}

Winter Rainfall Events in a Humid Karst Region

Weihong Yan ${ }^{\mathrm{a}}$, Qiuwen Zhou ${ }^{\mathrm{a}, *}$, Dawei Peng ${ }^{\mathrm{a}}$, Xiaocha Wei ${ }^{\mathrm{a}}$, Xin Tang ${ }^{\mathrm{a}}$, Ershuang Yuan ${ }^{\mathrm{a}}$, Ya lin Wang ${ }^{\mathrm{a}}$, Chunmao Shi ${ }^{\mathrm{a}}$

${ }^{a}$ School of Geography and Environmental Science, Guizhou Normal University, 550001 Guiya ng, People’s Republic of China; yanwh1210@163.com (W. Y.); peng_dawei@163.com (D. P.); x iaocha_wei@163.com (X. W.); 984170361@qq.com (X. T.); 2515195146@qq.com (E. Y.); 351428 6848@qq.com (Y. W.); 130107966@qq.com (C. S.);

\section{* Correspondence: zouqiuwen@163.com; Tel.: +86-851-8322-7361}

Abstract: Humid karst ecosystems are fragile, with precipitation being the main source of soil moist ure recharge. The process of soil moisture recharge and usage varies by vegetation type. To analyze the dynamics of soil moisture under different vegetation types during rainfall events, we continuousl y monitored soil moisture in arable land, grassland, shrub, and forest areas at 10-minute intervals fro m November 6, 2019, to January 6, 2020.The arable land was used as a control group. Soil moistur e under the different vegetation types responded to light, moderate, and rainstorm events with large $r$ ainfall amounts. However, only the soil moisture in the grassland areas responded to a light rainfall event with a rainfall amount of $0.87 \mathrm{~mm}$. The largest soil moisture recharge $(12.63 \mathrm{~mm})$ and decline $(2.08 \%)$ were observed for the grassland areas, with the smallest observed for the forest areas. Whi le the grassland areas showed the greatest decline in soil moisture following rainfall, they were mor e easily recharged during the winter rainfall events. Soil moisture in forests and shrubs was less rec harged than in grasslands but also declined less. Therefore, forests and shrubs are better at retaining soil moisture in winter, which is informative for the formulation of a regional vegetation recovery $\mathrm{m}$ odel. 


\section{1. Introduction}

Soil moisture plays an important role in the growth of vegetation (Brantley et al. 2017; Laio et al. 2001). Vegetation can affect soil moisture and its response to precipitation via many complex and interacting hydrological processes (Canton et al. 2016; Chen et al. 2007; Daly and Porporato 2005; Rivera et al. 2014). There are differences in the characteristics of the canopy and root distributions of different vegetation types, and these differences affect the response of soil moisture to rainfall (G ehrels et al. 1998). Therefore, it is important to study the responses of soil moisture to rainfall in ka rst regions with different vegetation types.

The responses of soil moisture under different vegetation types to rainfall have been studied by several researchers. The amount and period of rainfall varies in regions with different humidity cond itions. Soil moisture under the same vegetation type has different response characteristics in regions with different humidity conditions. In arid regions, the soil moisture in shrub areas is more sensitive to rainfall than that in grassland or forest areas (Sun et al. 2015; Wang et al. 2008). For example, S un et al. (2015) studied the soil moisture dynamics in shrub, forest, and grassland areas in arid regio ns and found that soil moisture in shrub areas is the most sensitive to single rainfall events. Convers ely, in semi-arid regions, soil moisture in grassland areas is more sensitive to rainfall than that in sh rub or forest areas (Li et al. 2013; Su and Shangguan 2019; Tang et al. 2019; Yu et al. 2018). For e xample, Li et al. (2013) studied the soil moisture dynamics in shrub and grassland areas in semi-ari 
$\mathrm{d}$ regions and found that grassland soil moisture is more sensitive to summer rainfall than shrub soil moisture. In sub-humid regions, the response of grassland soil moisture to rainfall is more sensitive ive to rainfall than shrub and forest soil moisture. Meanwhile, in humid regions, Zhu et al. (2014) st udied the responses of grassland and forest soil moisture to rainfall and found that their sensitivities to rainfall are similar. may not necessarily be representative of humid karst regions. This is because karst environments usu ally have different characteristics from non-karst environments (Hartmann et al. 2014; Li et al. 202 0). Karst environments are usually characterized by a shallow soil layer, high soil permeability, and complex topography (Bonacci et al. 2009; Dai et al. 2017; Fu et al. 2016b; Sohrt et al. 2014). in karst regions. For all the different vegetation types, the response of soil moisture to rainfall under heavy rainfall conditions is more sensitive than that under light and moderate rainfall conditions. $\mathrm{T}$ he variation in the soil moisture at different soil depths is also known to decrease with increasing so 
found that the response times of shallow soil moisture under different types of vegetation to rainfall

61 in summer are significantly different and that the response is faster under heavy rainfall conditions $t$

62 han under light and moderate rainfall conditions. Zhang et al. (2013) studied the changes in the soil

63 moisture under different vegetation types throughout the year and found that, when the rainfall is lig

ht, the soil moisture does not change significantly, while when the rainfall is heavy, the soil moistur e content changes significantly over a short period of time. Even though multiple researchers have st udied the responses of soil moisture under different vegetation types to precipitation in karst regions, these results do not represent the situation in winter. Therefore, our understanding of the characteris tics of soil moisture responses to winter rainfall events under different vegetation types in karst regi ons remains incomplete.

In humid karst regions, soil moisture in winter affects both plant growth and hydrological proce sses. On the one hand, because the winter temperature is not too low, the growth of plants is suppor ted by a certain amount of water and water conditions can threaten plant growth (Ding et al. 2020; Li et al. 2019; Zhang et al. 2012). On the other hand, even though there is less precipitation in hum id karst regions in winter, the change in the soil moisture is still an important part of the hydrologic al process and the ability of the soil to regulate and store water is more important in winter than in summer (Fu et al. 2016a; Yang et al. 2019). Therefore, it is important to study the response process es of the soil moisture under different vegetation types to winter rainfall in humid karst regions. Accordingly, this study investigates the response processes of soil moisture under different vege tation types to different rainfall intensities in winter. We conducted in-situ observations of soil moist 

karst regions.

\section{2. Materials and Methods}

\section{$84 \quad 2.1$ Overview of the Sample Plots}

The study area was located in Guanling County, Guizhou Province, China $\left(25^{\circ} 34^{\prime}-26^{\circ} 05^{\prime} \mathrm{N}\right.$,

$\left.105^{\circ} 15^{\prime}-105^{\circ} 49^{\prime} \mathrm{E}\right)$. With complex landform types and an extensive distribution of carbonate rock

$\mathrm{s}$, it is one of the most typical areas of karst landform development in Guizhou. The climate in Gua nling is primarily based on the humid mid-subtropical monsoon. The annual average temperature is $16.2^{\circ} \mathrm{C}$, rainfall is abundant, and the annual precipitation is $1205.1-1656.8 \mathrm{~mm}$ (Chen et al. 2018). $\mathrm{T}$ he rainfall is mostly concentrated from June to August. To eliminate the influence of other environm ental factors besides vegetation type and related factors among the sample plots, all sample plots we re located on the same slope (Figure 1), with an altitude of approximately $700 \mathrm{~m}$, a slope direction of NE, and an inclination of approximately $30^{\circ}$. The main type of soil in the area is limestone. The main vegetation in the study area is artificially planted corn and plantain, as well as naturally restor ed secondary grasslands, shrubs, and woodlands. The vegetation information and soil background of the different vegetation types are given in Table 1.

97

$$
\text { Table 1. Overview of the plots of the various vegetation types. }
$$

\begin{tabular}{cccccc}
\hline $\begin{array}{c}\text { Plots of } \\
\text { different }\end{array}$ & Vegetation & Vegetation & Vegetation & Soil bulk & Soil organic \\
vegetation & Types & coverage & height $(\mathbf{m})$ & density & matter \\
types & & $(\%)$ & & $\mathrm{g} / \mathrm{cm})$ & content $(\mathrm{g} / \mathrm{kg}$ \\
& & & & & ) \\
\hline
\end{tabular}




\begin{tabular}{|c|c|c|c|c|c|}
\hline Arable & I & l & I & 1.22 & 28.95 \\
\hline \multicolumn{6}{|l|}{ Land } \\
\hline \multirow[t]{5}{*}{ Grassland } & Blumea balsamifera & $30 \%$ & $0.6 \mathrm{~m}$ & 1.15 & 49.23 \\
\hline & (Linn.); Ageratum & & & & \\
\hline & conyzoides Sieber ex & & & & \\
\hline & Steud; Arthraxon hispidus & & & & \\
\hline & (Thunb.) Makino et al. & & & & \\
\hline \multirow[t]{6}{*}{ Shrub } & Cipadessa cinerascens & $50 \%$ & $3.4 \mathrm{~m}$ & 1.11 & 68.15 \\
\hline & (Pellegr.) Hand -Mazz; & & & & \\
\hline & Albizia kalkora (Roxb.) & & & & \\
\hline & Prain;Mallotus japonicas & & & & \\
\hline & var. floccosus (Muell. & & & & \\
\hline & Arg.) S. M. Hwang et al. & & & & \\
\hline \multirow[t]{5}{*}{ Forest } & Radermachera sinica & $65 \%$ & $15 \mathrm{~m}$ & 1.04 & 70.90 \\
\hline & (Hance) Hemsl; Toona & & & & \\
\hline & sinensis (A. Juss.) & & & & \\
\hline & Roem;Broussonetia & & & & \\
\hline & papyrifera et al. & & & & \\
\hline
\end{tabular}

98

$99 \quad 2.2$ Experimental Design and Data Collection

Five plots were randomly selected from each vegetation type; the size of each plot was $5 \mathrm{~m} \times$

$1015 \mathrm{~m}$; and the plot spacing was approximately $20 \mathrm{~m}$. The HOBO H21_USB soil moisture monitoring system was used in each plot to monitor the soil moisture content at four soil depths $(5 \mathrm{~cm}, 10 \mathrm{~cm}$, $15 \mathrm{~cm}$, and $20 \mathrm{~cm}$ ). The data collection frequency was $10 \mathrm{~min}$, and the monitoring time was from November 6, 2019, to January 6, 2020. Because of the shallow soil depth on the karst slope, the sa mple plots selected in this study usually contained a large amount of gravel or reached the bedrock at approximately $30 \mathrm{~cm}$ below the surface, even though the soil thickness varied greatly. Therefore, $\mathrm{t}$ he maximum depth of the soil profile observations was set to $20 \mathrm{~cm}$. The rainfall observations were 
measured using a rain gauge (RG3-M) with an accuracy of $0.2 \mathrm{~mm}$. Because of the distance betwee $\mathrm{n}$ the different sites, a total of three rain gauges were installed throughout the sample plots. The ave rage value of three rain gauges represents the rainfall in the four types of plots.

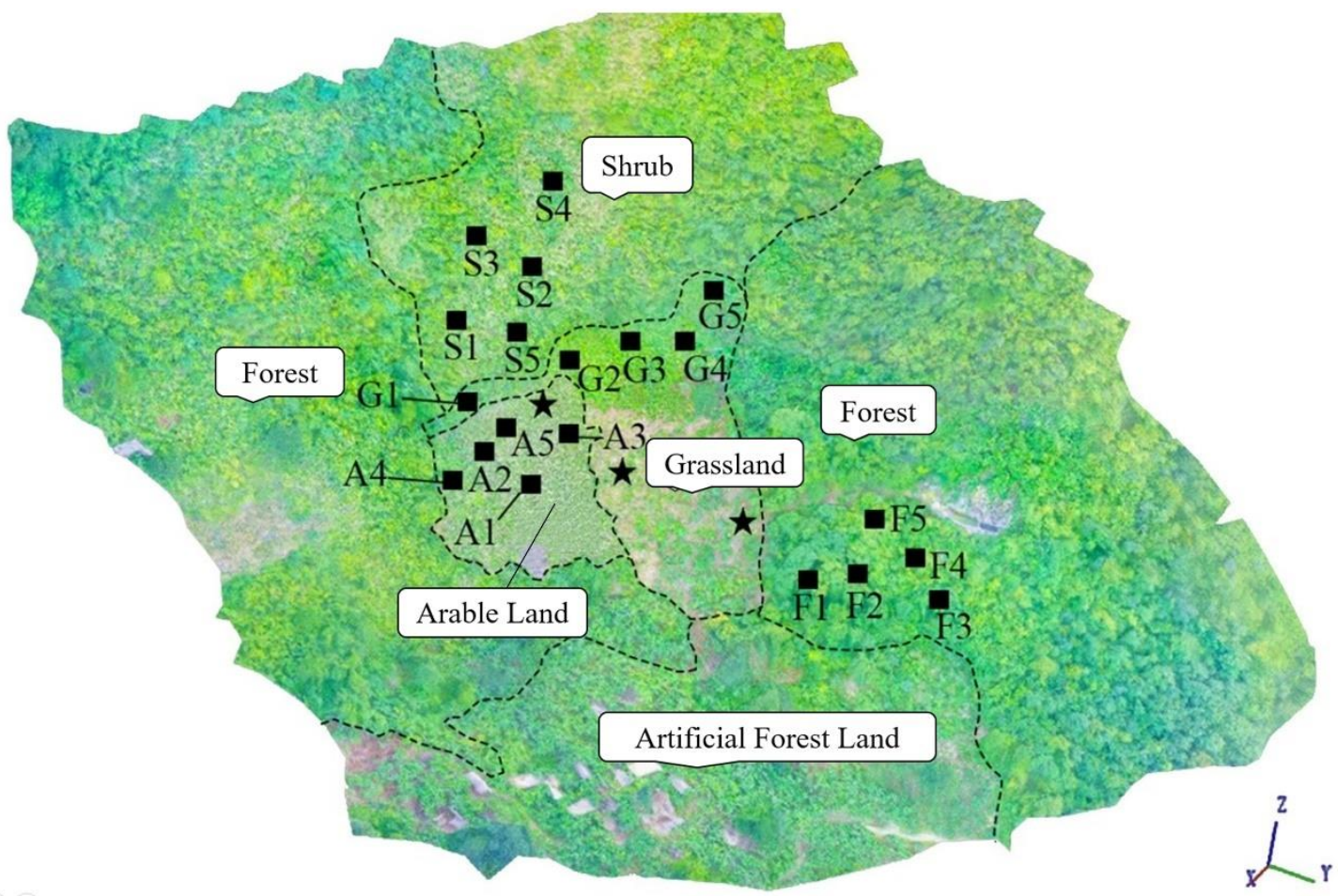

Figure 1. Distribution map of the sample plots. A1-A5 indicate arable land plots; G1-G5 indicate g rassland plots; S1-S5 indicate shrub plots; and F1-F5 indicate forest plots. The $\star s$ indicate rain ga uges.

\subsection{Data Analysis}

In this study, the soil moisture responses under the different vegetation types to different rai nfall events were analyzed. The soil moisture $10 \mathrm{~min}$ prior to the start of a rainfall event was ta ken as the initial value of the soil moisture. The response characteristics under the different vege tation types were analyzed by observing the changes in the soil moisture $12 \mathrm{~h}$ after the end of a rainfall event. The following equations (Yang et al. 2018) are used to calculate the change char 
The increase in soil moisture is calculated as

where $\Delta \theta_{i}$ indicates the soil moisture rise rate $(\%) ; \theta_{\max }$ indicates the peak soil moisture durin

$\mathrm{g}$ rainfall; and $\theta_{0}$ indicates the soil moisture (\%) $10 \mathrm{~min}$ prior to the start of the rainfall event.

The extent of soil moisture decline is calculated as

$$
\Delta \theta_{i}=\theta_{\max }-\theta_{0}
$$

where $\Delta \theta_{d}$ indicates the soil moisture drop rate (\%) and $\theta_{e}$ indicates the soil moisture (\%) 12

$h$ after the end of the rainfall event. e i-th layer (\%); and $d_{i}$ indicates the thickness of the soil layer $(\mathrm{cm})$. soil moisture storage after the rainfall event $(\%)$; and $S W_{0}$ indicates the initial value of the soil mois ure content at different soil depths under the different vegetation types. Origin 2018 and R (4.0.2) w 


\section{Results}

143

144

145

146

147

148

149

150

151

152

\subsection{Rainfall Characteristics during the Study Period} rainstorm events accounted for $6.7 \%$ of the total rainfall events.

Table 2. Classification of the rainfall intensity and the number of each type of rainfall event dur ing the experiment.

\begin{tabular}{ccc}
\hline Precipitation type & Rainfall in $24 \mathrm{~h}(\mathrm{~mm})$ & Events \\
\hline Light rain & $<10$ & 12 \\
Moderate rain & $10-25$ & 2 \\
Heavy rain & $25-50$ & 0 \\
Rainstorm & $50-100$ & 1 \\
\hline
\end{tabular}

\subsection{Dynamics of the Mean Soil Moisture and Precipitatio}

\section{n Distribution}

Figure 2 shows the temporal dynamics of the mean soil moisture and precipitation distributio $\mathrm{n}$ for the three different vegetation types in the karst region. During the study period, the mean 
soil moisture under the three different vegetation types all responded positively to rainfall. During the period from November 6 to 28 , the order of the mean soil moisture content under the diffe rent vegetation types was shrub $>$ grassland $>$ arable land $>$ forest. After November 28, the mea n soil moisture content in the shrub areas was the highest; this trend continued until December 2 0. After December 20, the order of the mean soil moisture content under the different vegetation types was arable land $>$ shrub $>$ grassland $>$ forest. During the entire study period, the mean soi 1 moisture content in the forest areas was the lowest, ranging from $23.04 \%$ to $32.08 \%$.

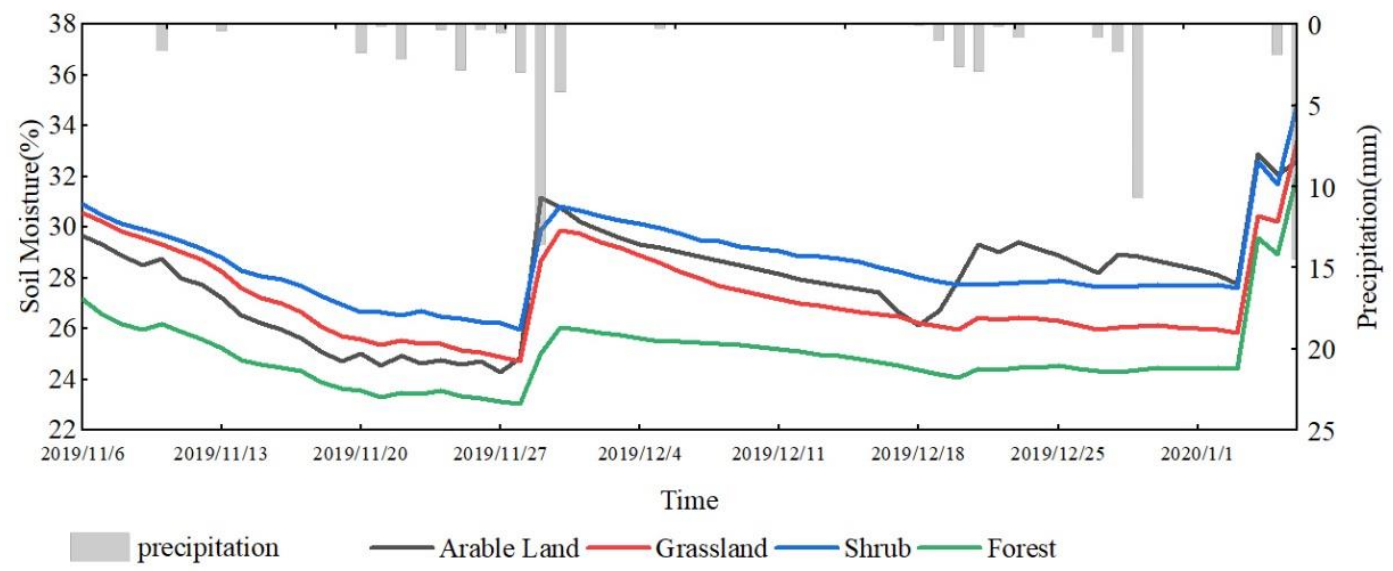

Figure 2. Dynamic changes in the mean soil moisture content and precipitation distribution for $t$ he different vegetation types.

\subsection{Soil Moisture Characteristics of the Different Soil Lay}

\section{ers during the Study Period}

Wilcoxon tests were performed on the soil moisture data (Figure 3) and revealed significant differences $(\mathrm{p}<0.001)$ in the soil moisture content in all four soil layers under the different veg etation types. A comparison of the median soil moisture in different soil layers revealed that the overall soil moisture content under the different vegetation types showed a tendency to increase 
176 ile the difference in the soil moisture content in the $15-\mathrm{cm}$ and $20-\mathrm{cm}$ soil layers in the grasslan
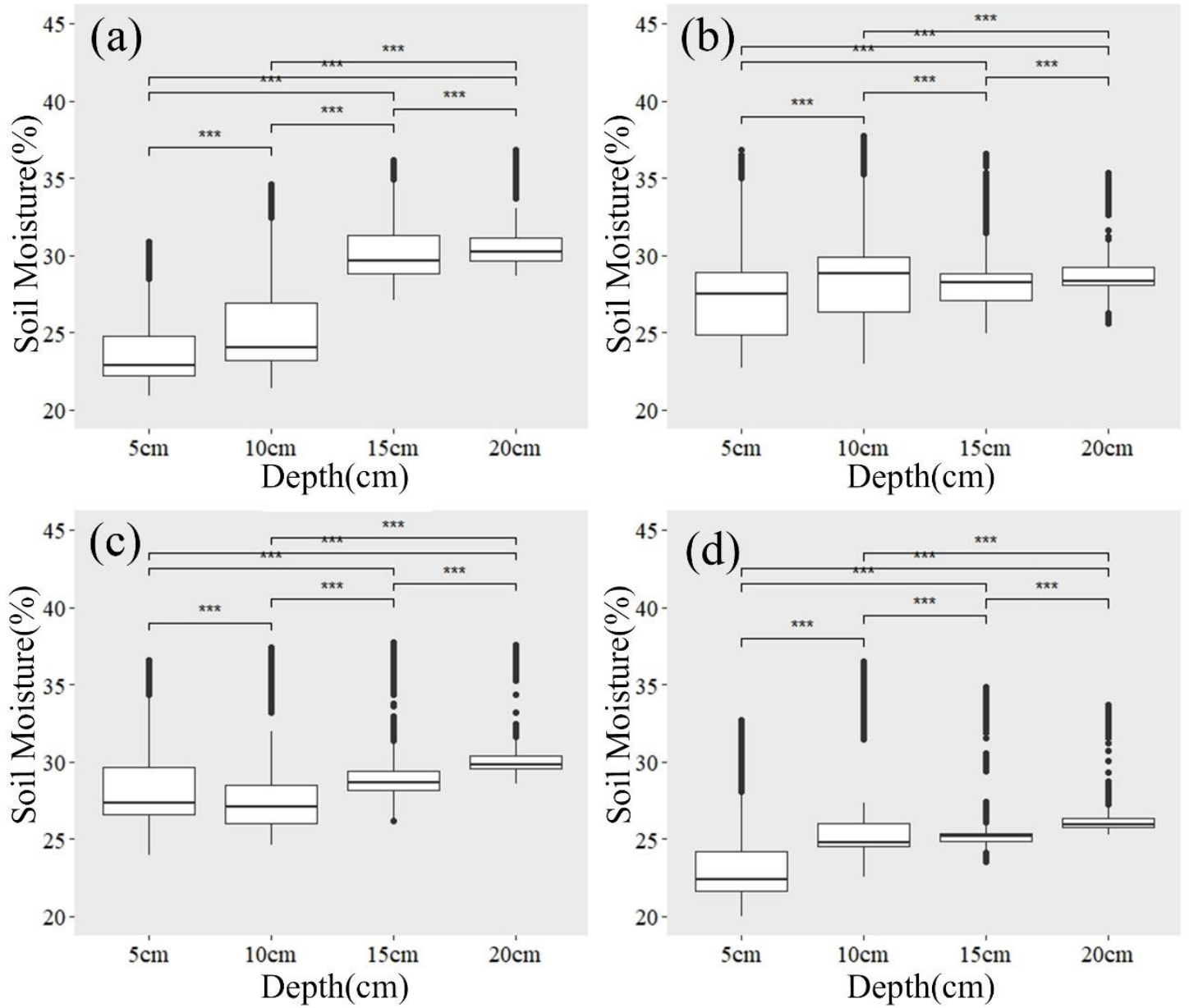

180 Figure 3. Characteristics of the soil moisture in the different soil layers under the different veget ation types: (a) arable land; (b) grassland; (c) shrub; and (d) forest. 


\subsection{Responses of Soil Moisture under Different Vegetation}

\section{Types to Light Winter Rainfall Events}

In the analysis of the light rainfall events, two rainfall events with similar average rainfall $\mathrm{i}$ ntensities but different total rainfall amounts were selected for analysis. In the first light rainfall event (Figure 4), the total rainfall was $0.87 \mathrm{~mm}$ and the rainfall duration was $2.17 \mathrm{~h}$. During the entire rainfall event, the soil moisture of the different soil layers in the arable land, shrub, and forest areas did not fluctuate significantly. The soil moisture content in the $5-\mathrm{cm}, 10-\mathrm{cm}$, and $15-$ $\mathrm{cm}$ soil layers in the grassland areas had a strong response to the rainfall event, while the soil moisture content in the 20 -cm soil layer had a weak response. After the rainfall event, the soil moisture content of the four different soil layers in the grassland areas all began to increase and reached peak values. The order of the peak soil moisture content was $15 \mathrm{~cm}>20 \mathrm{~cm}>10 \mathrm{~cm}$ $>5 \mathrm{~cm}$. In the $5-15-\mathrm{cm}$ soil layers, the time for the soil moisture to reach its peak increased with the soil depth. The greatest rise in the soil moisture content was observed in the 5 -cm laye $\mathrm{r}$, followed by the $15-\mathrm{cm}$ and $10-\mathrm{cm}$ layers, and the smallest rise in the soil moisture was obser ved in the $20-\mathrm{cm}$ layer. The decline in the soil moisture content was greatest in the $5-\mathrm{cm}$ soil la yer and smallest in the 20 -cm soil layer. 

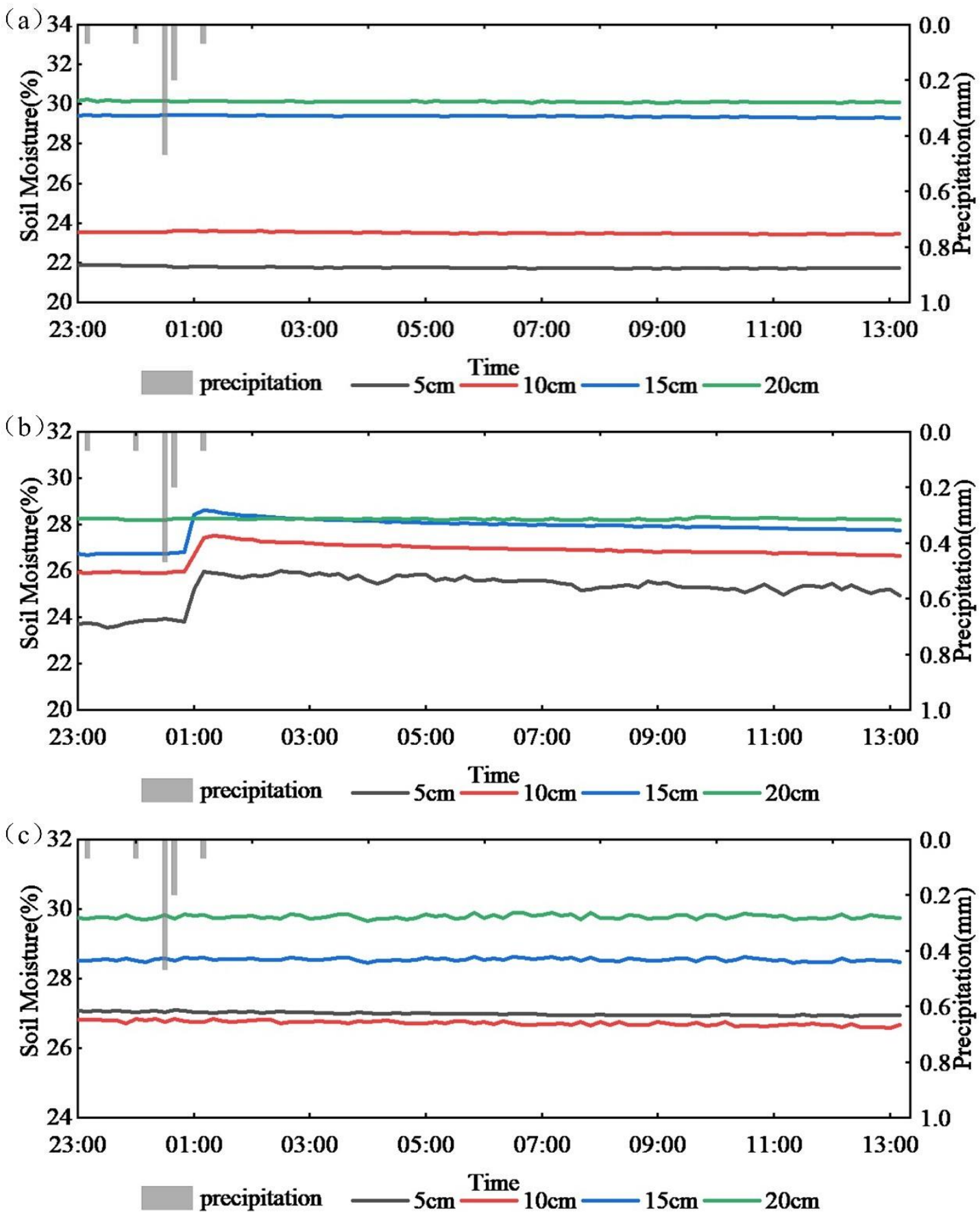


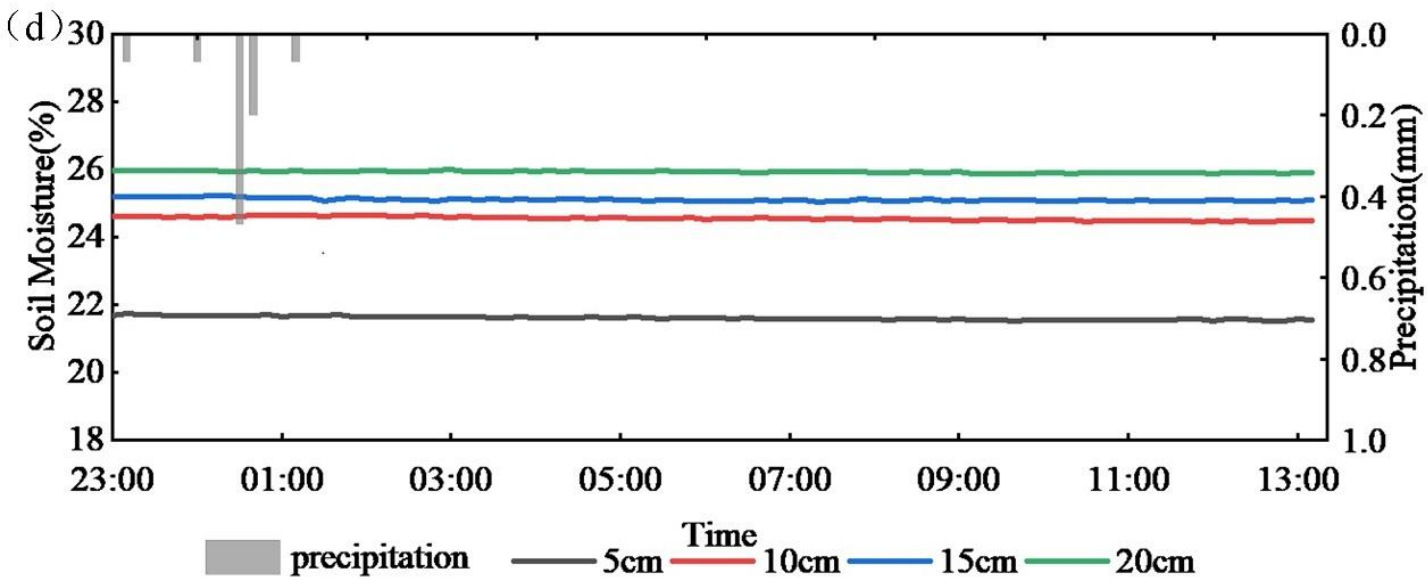

199 Figure 4. Responses of soil moisture under the different vegetation types to rainfall: (a) arable la

200 nd; (b) grassland; (c)shrub; and (d) forest.

201 In the second light rainfall event (Figure 5), the total rainfall was $20.75 \mathrm{~mm}$ and the rainfal

2021 duration was $54.17 \mathrm{~h}$. There were fluctuations in the soil moisture content at the different soil

203 depths under the three different vegetation types. After the rainfall event occurred, the soil moist

204 ure content in the arable land, grassland, shrub, and forest areas gradually increased and reached

205 a peak. In the arable land areas, the peak value of the soil moisture content increased with incre

206 asing soil depth, while the grassland, shrub, and forest areas generally had peak values of the so

207 il moisture content in the shallow layers $(5 \mathrm{~cm}$ and $10 \mathrm{~cm})$ that were larger than those in the $\mathrm{d}$

208 eep layers $(20 \mathrm{~cm}$ and $15 \mathrm{~cm})$. The peak time of the surface soil moisture was the smallest in $\mathrm{t}$

209 he arable land areas $(37.17 \mathrm{~h})$, and the grassland, forest, and shrub areas lagged by $0.5 \mathrm{~h}, 3.83$

$210 \mathrm{~h}$, and $5.16 \mathrm{~h}$, respectively. The rise in the soil moisture content under the different vegetation ty

211 pes showed a general tendency to be greater in the shallow layers $(5 \mathrm{~cm}$ and $10 \mathrm{~cm})$ than in th

212 e deep layers $(15 \mathrm{~cm}$ and $20 \mathrm{~cm})$. Both the increase and decrease in the soil moisture content $\mathrm{w}$

213 ere highest in the grassland areas and lowest in the forest areas. 


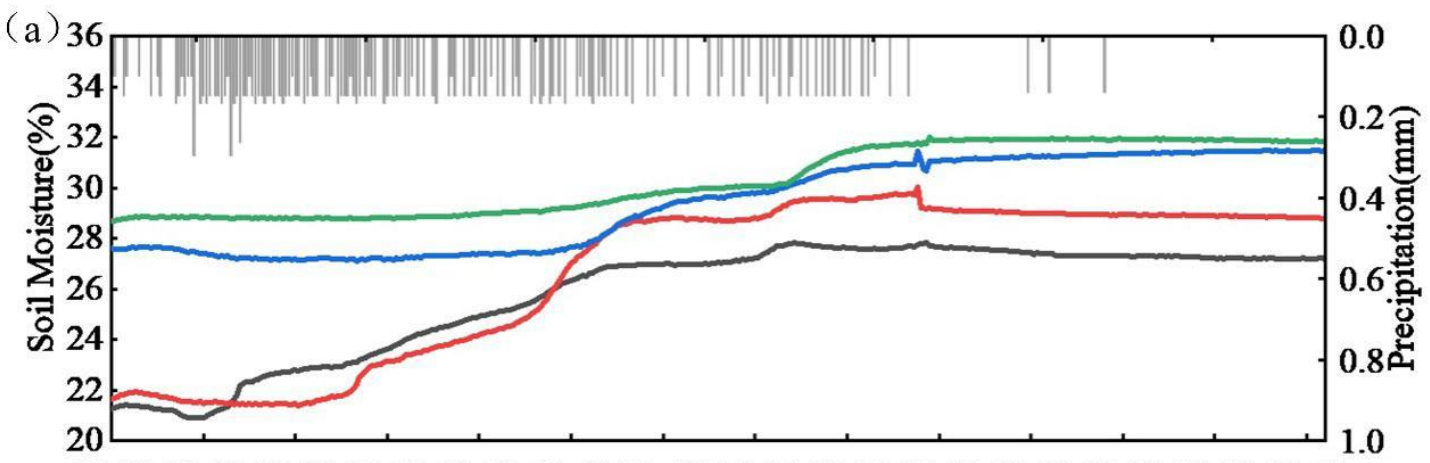

17:50 22:50 03:50 08:50 13:50 18:50 23:50 04:50 09:50 14:50 19:50 00:50 05:50 10:50

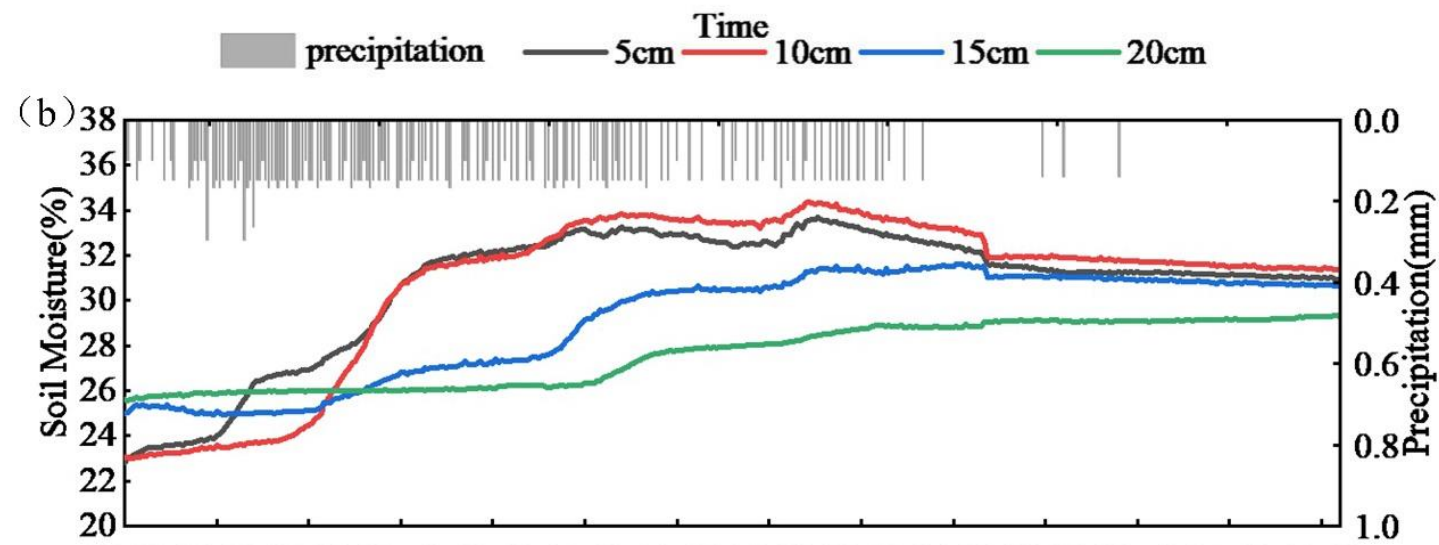

17:50 22:50 03:50 08:50 13:50 18:50 23:50 04:50 09:50 14:50 19:50 00:50 05:50 10:50

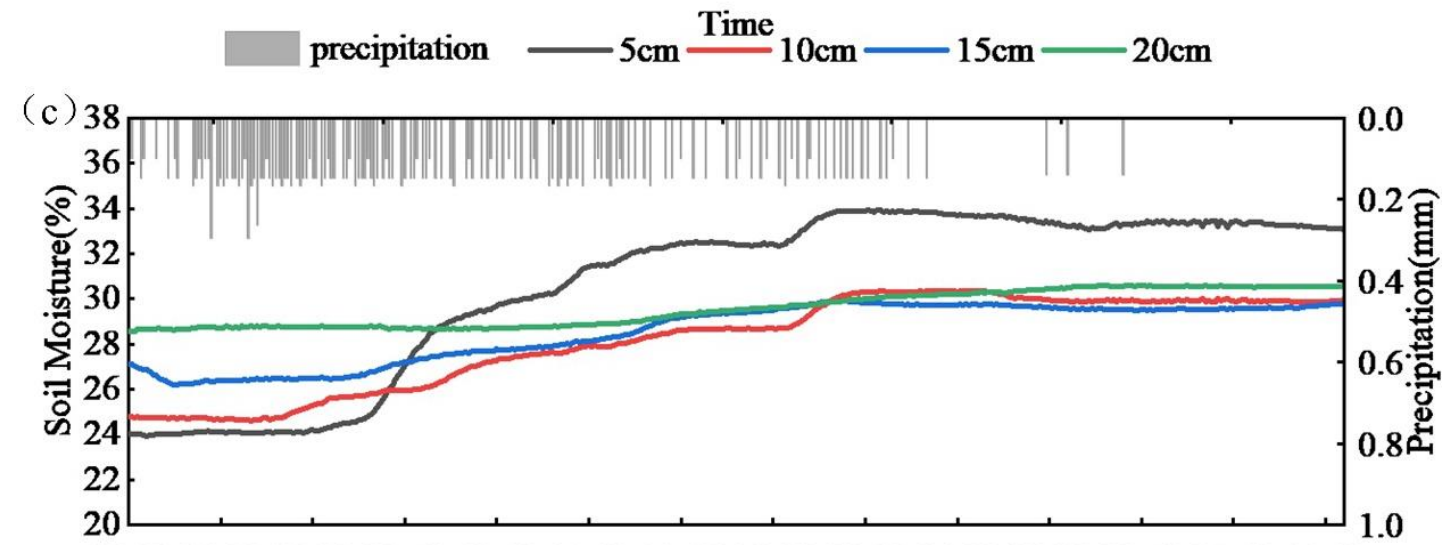

17:50 22:50 03:50 08:50 13:50 18:50 23:50 04:50 09:50 14:50 19:50 00:50 05:50 10:50 precipitation $-5 \mathrm{~cm} \stackrel{\text { Time }}{-} 10 \mathrm{~cm}-15 \mathrm{~cm}-20 \mathrm{~cm}$ 


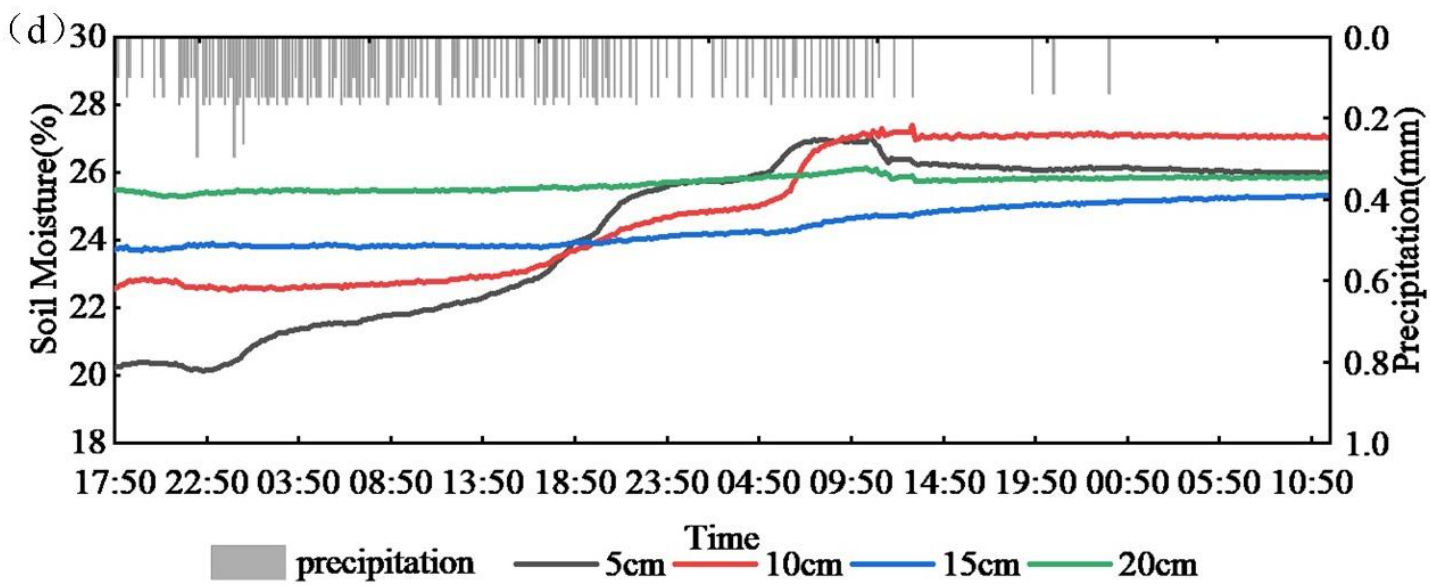

214 Figure 5. Responses of soil moisture under the different vegetation types to rainfall: (a) arable la 215 nd; (b) grassland; (c) shrub; and (d) forest.

\subsection{Responses of Soil Moisture under Different Vegetation} $y$ to the moderate rainfall event (Figure 6). The order of the peak values of the surface soil moi sture content under the different vegetation types was grassland $>$ shrub $>$ forest $>$ arable land. The peak time of the surface soil moisture was $25.5 \mathrm{~h}$ in the grassland areas, with a lag of 2.5 in the soil moisture content was found in the shrub areas, and the smallest was found in the gr assland areas. The greatest decline in the soil moisture content occurred in the grassland areas, a nd the smallest occurred in the arable land areas. 

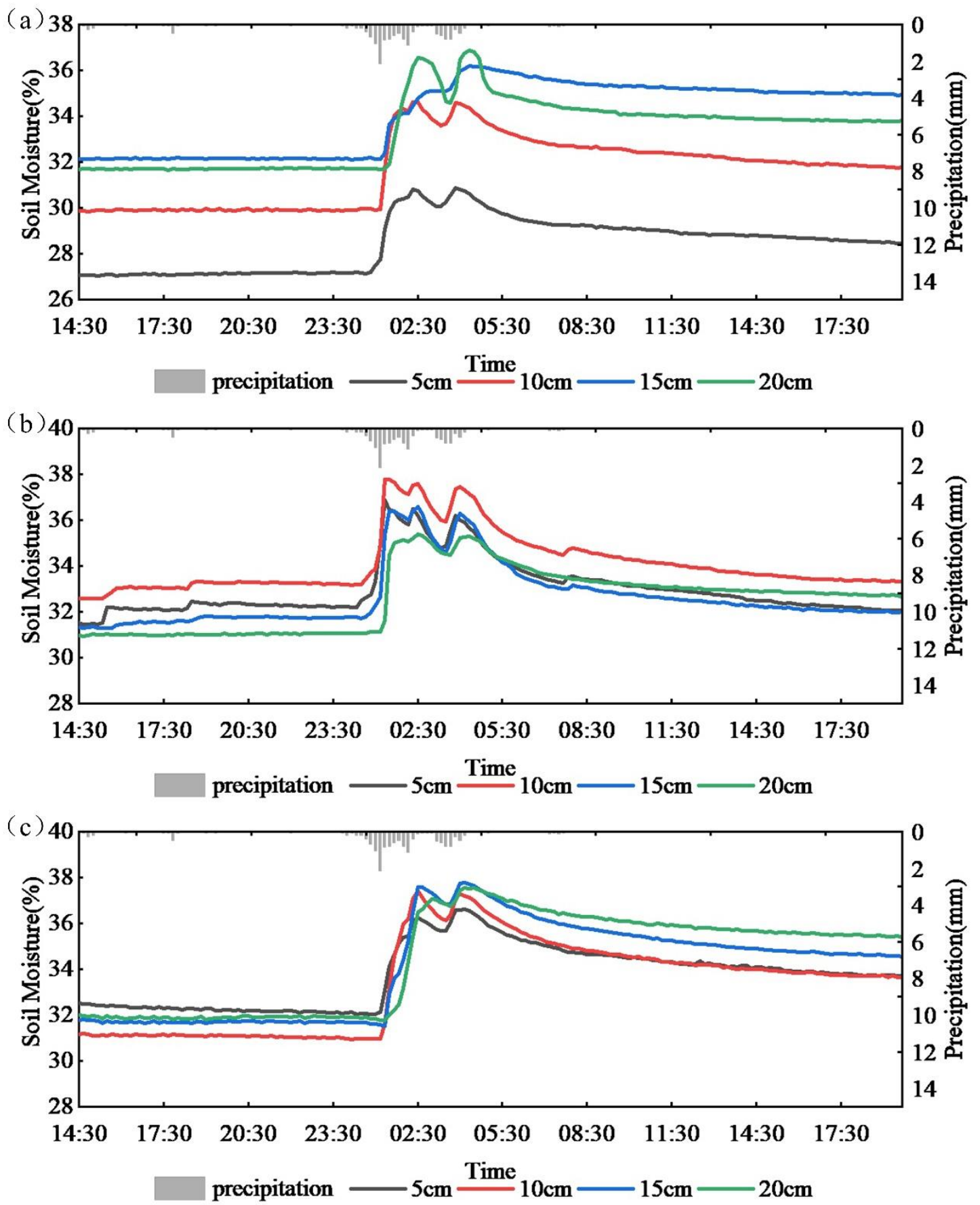


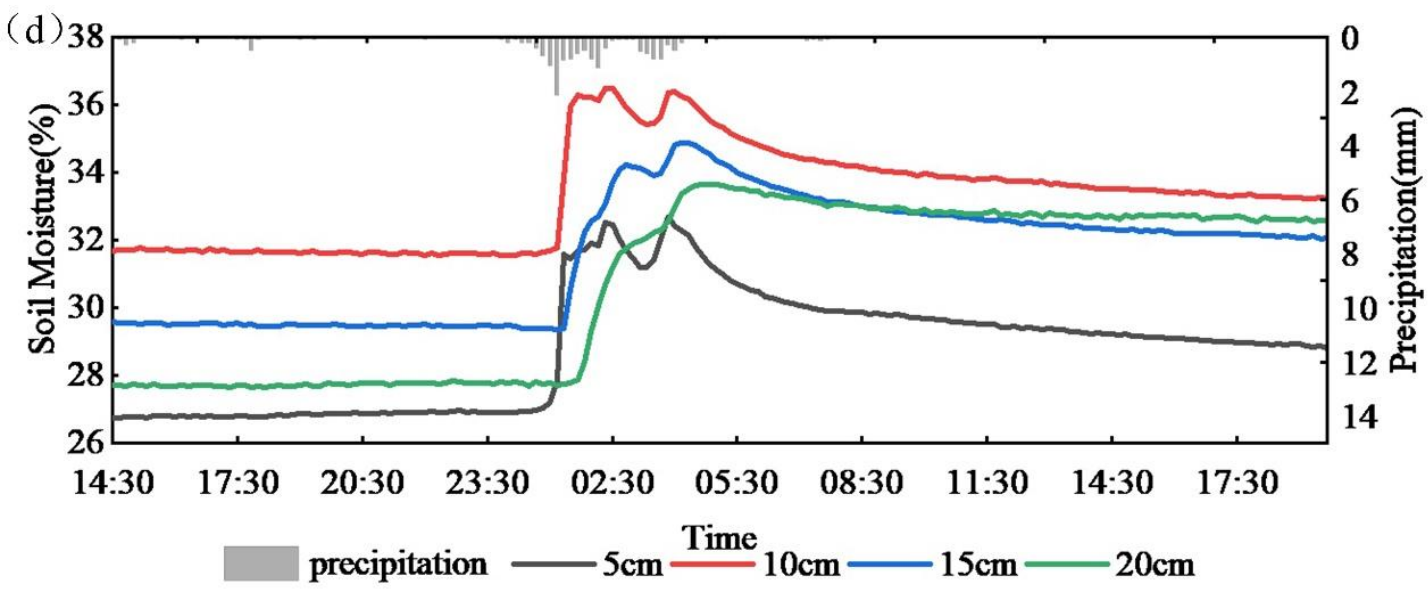

Figure 6. Responses of soil moisture under the different vegetation types to rainfall: (a) arable la nd; (b) grassland; (c) shrub; and (d) forest.

\subsection{Responses of Soil Moisture under Different Vegetation} der the different vegetation types was grassland $>$ shrub $>$ forest $>$ arable land. The peak time $\mathrm{f}$ or the surface soil moisture content was $0.67 \mathrm{~h}$ in the forest areas and lagged by $0.16 \mathrm{~h}, 1 \mathrm{~h}$, a nd $1.16 \mathrm{~h}$ in the grassland, shrub, and arable land areas, respectively. The greatest increase in th e soil moisture content was in the grassland areas, and the smallest was in the arable land areas. as in the arable land areas. 

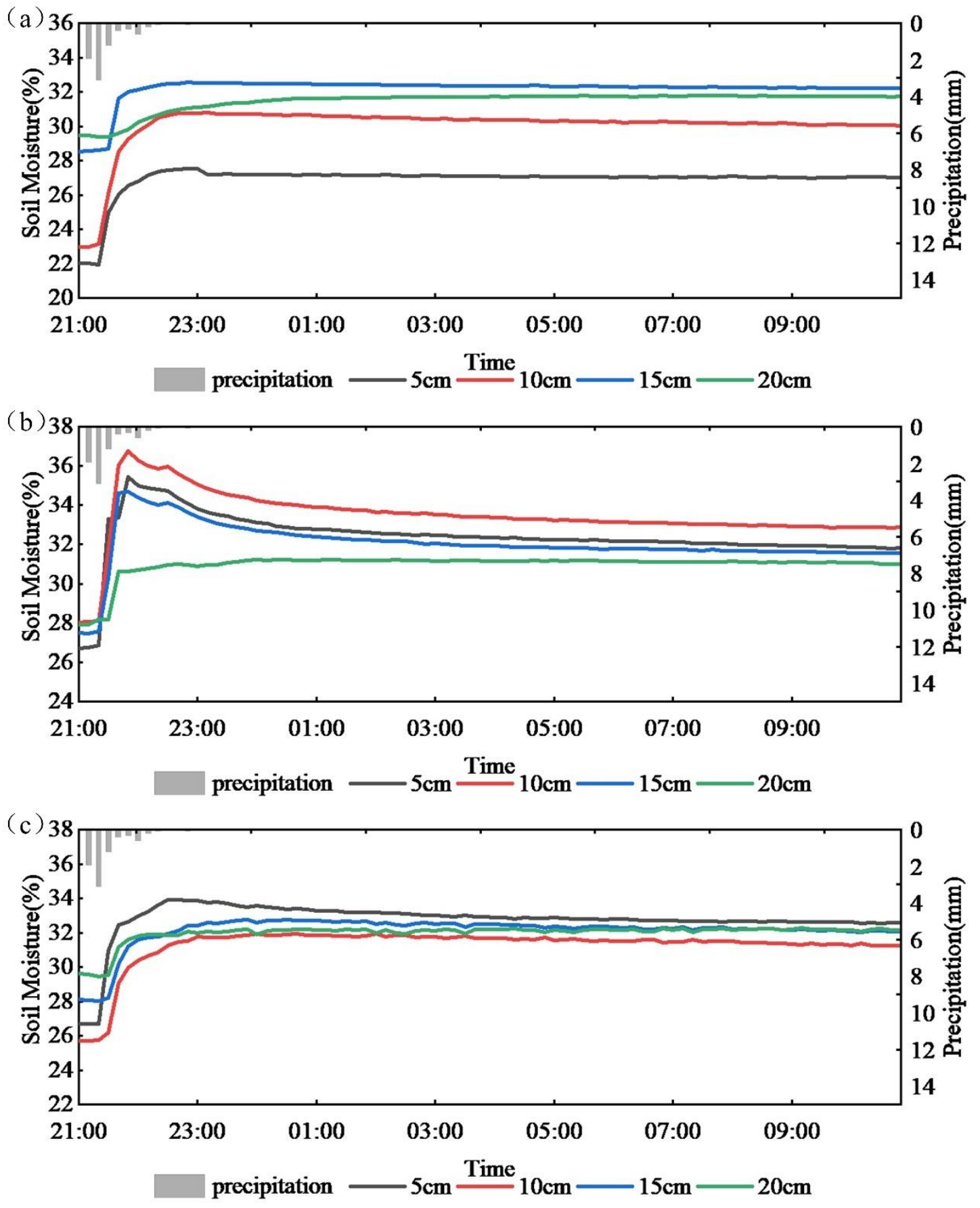


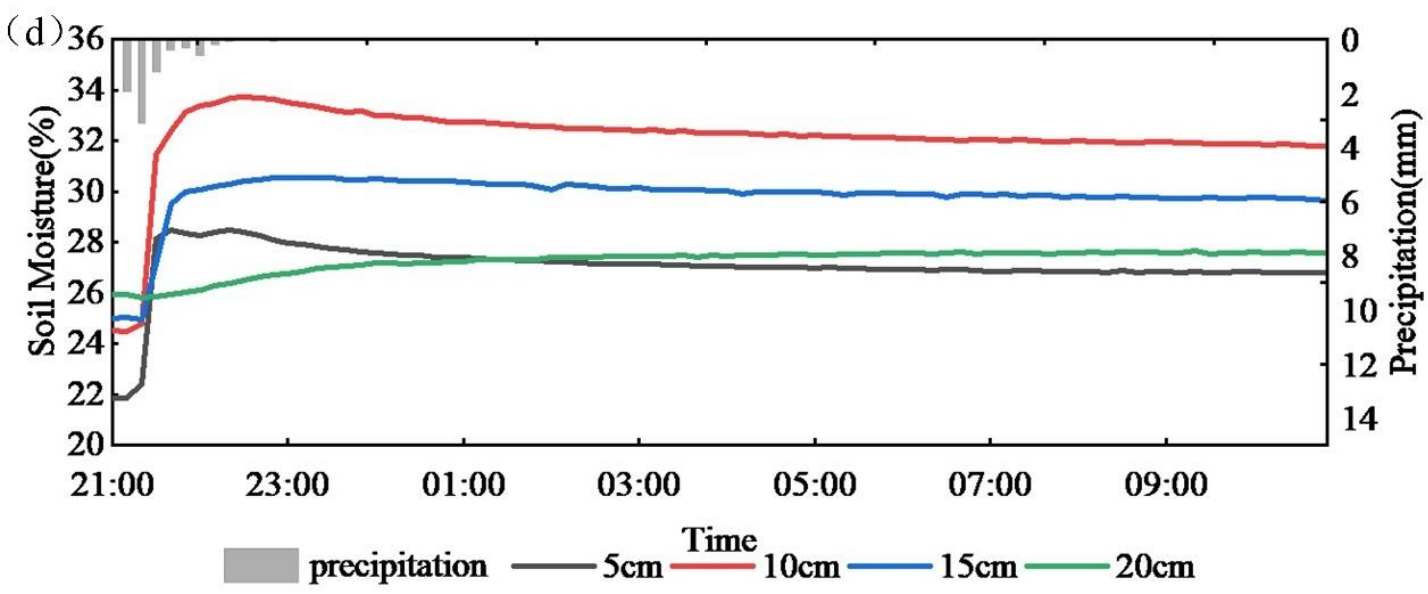

241 Figure 7. Responses of soil moisture of different vegetation types to rainfall: (a) arable land; (b) 242 grassland; (c) shrub; and (d) forest.

\section{Discussion}

\subsection{Responses of the soil moisture under different vegetat} ion types to different winter rainfall events g et al. 2015). Guo et al. (2016), who studied the process of soil moisture responses to rainfall on karst slopes in autumn, showed that $6 \mathrm{~mm}$ of rainfall is the threshold for a soil moisture res ponse, which is different from the results of our study. In our study, the soil moisture in the dif ferent soil layers $(0-20 \mathrm{~cm})$ of the grassland areas responded to a winter rainfall event with a to tal rainfall of only $0.87 \mathrm{~mm}$ likely because grassland areas have a smaller ability to trap rainfall, allowing the smaller total rainfall to pass through the grassland vegetation and reach the soil. In the studied humid karst region, the soil moisture in the $0-20-\mathrm{cm}$ soil layers under the different 
vegetation types responded to light $(20.75 \mathrm{~mm}$ total rainfall), moderate $(16.33 \mathrm{~mm}$ total rainfall), and rainstorm (7.9 $\mathrm{mm}$ total rainfall) winter rainfall events.

Rainfall intensity is an important influence on soil moisture variability (Zhang et al. 2016).

Han et al. (2016) studied changes in the soil moisture under artificial rainfall conditions in karst regions and found that the magnitude of the soil moisture changes increased with increasing rainf all intensity. In our study, the magnitude of the increase in the soil moisture under the different vegetation types during moderate and rainstorm events also increased with increasing rainfall inte nsity (Figure 8a), which is similar to the results of previous studies. We found that the variation in the soil moisture content of the arable land, grassland, and shrub areas was the largest for a 1 ight rainfall event (with a total rainfall amount of $20.75 \mathrm{~mm}$ ). The variation range of the soil $\mathrm{m}$ oisture content in the forest areas increased with increasing rain intensity. In the light rainfall eve nt, the soil moisture content of the arable land, grassland, and shrub areas experienced the larges $\mathrm{t}$ changes, mainly because the total amount of rainfall during the light rainfall event was relativel y large and the rainfall had a continuous impact on the soil water. Soil water in different vegeta tion types affects the soil response to rainfall. The response to the light rainfall event with a lar ge total rainfall amount was strong. Forest areas have large vegetative covers and a surface cove sity is more likely to enter forested soil. gures $8 \mathrm{~b}-8 \mathrm{~d}$ ). This is similar to the results of previous studies (Liu et al. 2013) in the spring an d summer in karst regions. This shows that the response of the soil moisture content in the soil 
281 fferent vegetation types during the moderate rainfall event. This indicates that the moderate rainfa
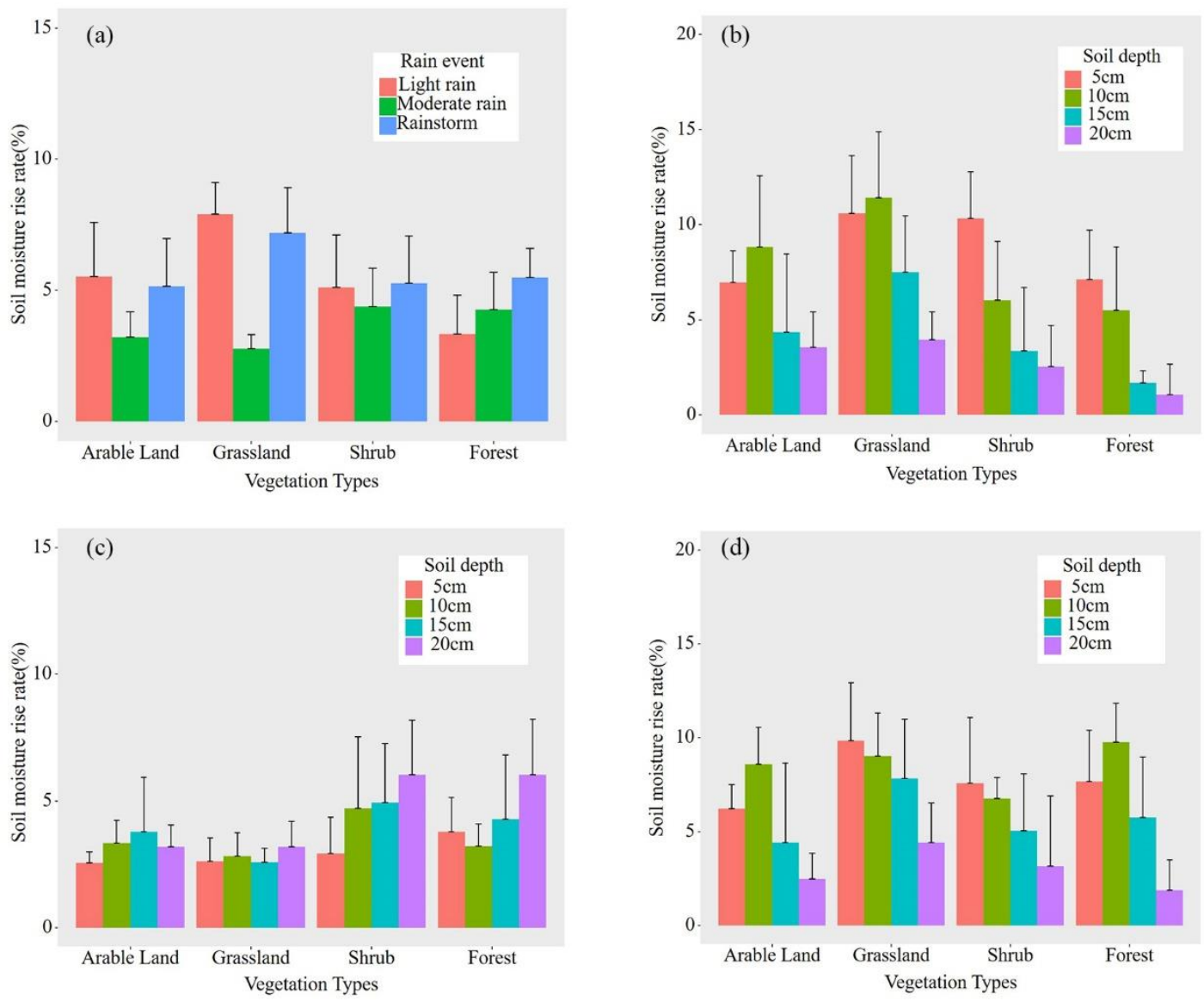

Figure 8. Statistical graphs of the increase in the soil moisture under the different vegetation typ

es (a) during three different rainfall events; (b) at different depths during a light rainfall event;

(c) at different depths during a moderate rainfall event; and (d) at different depths during a rains 


\subsection{Winter Soil Moisture Characteristics under the Differ}

\section{ent Vegetation Types}

Soil moisture varies with the season, and vegetation communities have different soil moisture content in different seasons (Gao et al. 2018). Considering the changes in the mean soil moistur e content under the four different vegetation types (Figure 2), we see that the shrub areas mainta ined a high mean soil moisture content while the forest areas had the lowest average soil moistu re content. This is consistent with previous studies (Chen et al. 2006) in summer in karst region s. The shrub areas maintained a high soil moisture content during the entire study period, which may be due to the large vegetative coverage of the shrubs and the poor light transmittance, whic $\mathrm{h}$ can effectively prevent soil water from evaporating. Therefore, the mean shrub soil moisture co ntent was relatively high. Soil moisture is a limiting factor for vegetation growth. In winter, amo ng the different vegetation types, the mean soil moisture content of the shrub areas was higher, which is beneficial to the growth of shrub communities. The mean soil moisture content in the $f$ orest areas was low, and this low mean soil moisture content may limit the growth of forest co mmunities.

There are significant differences in the soil moisture profiles under the different vegetation $t$ ypes, and the change in the soil moisture generally increases with increasing soil depth (Figure 3). This is consistent with the results of previous studies (Liu et al. 2005) in summer. The influ ence of external factors on the soil moisture weakens with increasing soil depth (Guber et al. 20 08; Zhao et al. 2020). Surface soil moisture is most affected by external factors, and the soil mo isture content is the smallest in the surface soil layer. External factors have less of an influence on the soil moisture in deeper soil layers. The deep soil layer maintains a high soil moisture co 


\section{4.3 Characteristics of Soil Moisture Replenishment under}

\section{Different Vegetation Types in Winter}

Different vegetation types tend to exhibit different recharge characteristics during the recharg

e of soil moisture by rainfall (Yang et al. 2018). Zhang et al. (2013) analyzed the dynamic patte rn of the soil moisture content in the depression profile of a karst region over a year and found that moderately intense, prolonged, and heavy rainfall is conducive to the compensation and reco th large total rainfall amounts and long durations) were analyzed to investigate the soil moisture recharge characteristics of the rainfall for the different vegetation types. The results showed that $t$ he soil moisture recharge was greatest in the grassland areas $(12.63 \mathrm{~mm})$ and smallest in the for est areas $(9.40 \mathrm{~mm})$ (Figure 9). Different vegetation types have different interception techniques. The smallest amount of soil moisture was recharged to the forest areas, likely because the rainfal soil in grassland areas. hich explains why the soil moisture replenishment in the shrub areas in this study was greater th an that in the forest areas. Among the different vegetation types, grasslands had the smallest abil 


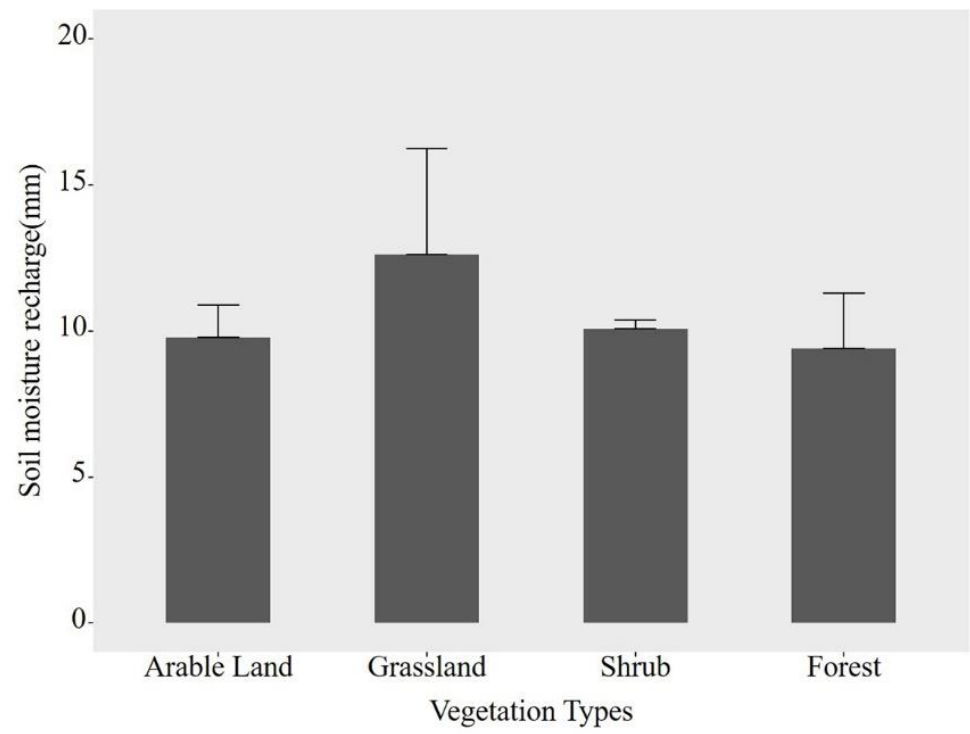

Figure 9. Soil moisture replenishment under the different vegetation types.

\subsection{Characteristics of the Soil Moisture Decline under the} their results showed that the decline in the soil moisture in shrub areas was greater than that in grassland areas. In our study, the decline in soil moisture was greater in the grassland areas (2.0 $8 \%$ ) than in the shrub areas $(1.03 \%)$, which differed from these previous findings (Figure 10). $\mathrm{T}$ his may be because the study of Yang et al. (2007) was primarily conducted in summer. There a re many types of vegetation in shrub communities, and the amount of plant transpiration is great er in shrub areas than in grassland areas. In karst regions, there is little rain or wind in winter and soil moisture evaporates continuously under dry conditions. Plant transpiration in winter is $\mathrm{w}$ 

sland areas was low, the exposed soil area was large, and the soil moisture of the grassland area s continued to evaporate under the dry winter conditions. The vegetative coverages of the forest $(0.88 \%)$ and shrub $(1.03 \%)$ areas were larger, and their surfaces were covered by a layer of litte r, which was less disturbed by the outside world. This also explains why grassland soil moisture decreases more than forest and shrub in winter. In winter, the arable land $(0.76 \%)$ is in a state of fallow, and its water consumption is the least, which can better maintain soil moisture in wint er.

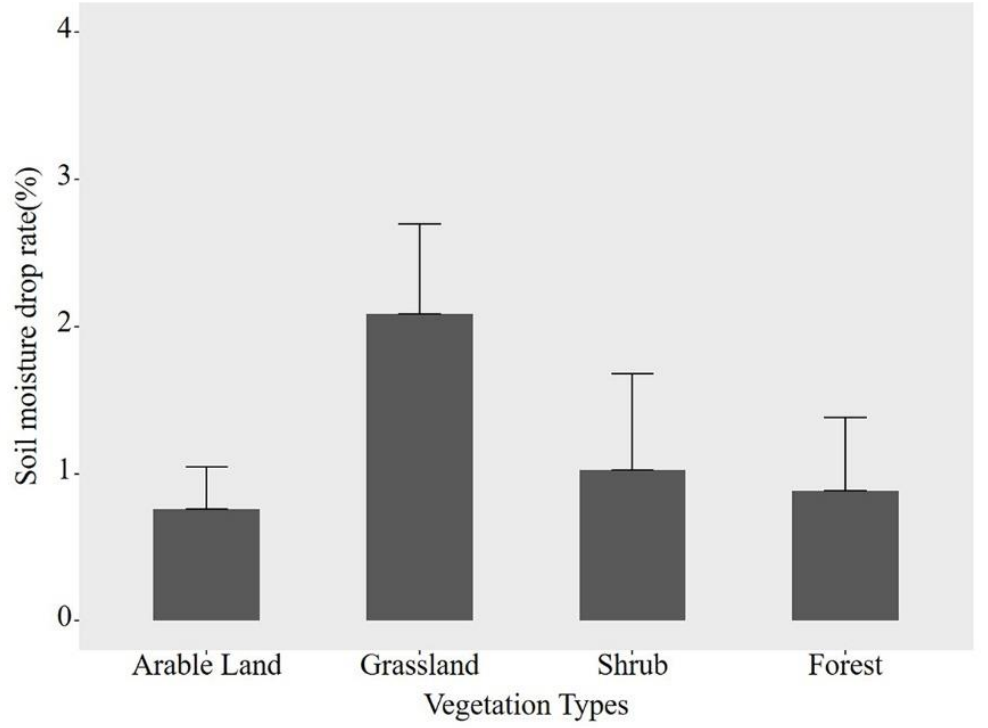

Figure 10 Statistical graph of the decline in soil moisture of different vegetation types 
vegetation types, only the soil moisture in different soil layers of grassland can respond to light rain events (the total rainfall is $0.87 \mathrm{~mm}$ ). The soil moisture under different vegetation types resp onds to light rain events, moderate rain events and rainstorm events with a large total rainfall. In the event of moderate rain and rainstorm rain, the variation range of soil moisture in the soil $\mathrm{p}$ rofile under different vegetation types increases with the increase of rainfall intensity. There are $s$ ignificant differences in soil moisture in the soil profile of different vegetation types, and the cha nges in soil moisture generally show a trend of increasing with the increase of soil depth. Shrub maintain a high mean soil moisture content, while forests have the lowest mean soil moisture co ntent. The replenishment and decline of soil moisture in grassland are both the largest, and the $r$ esults of forest land research are opposite to grassland.

\section{Data availability}

The datasets used and/or analysed during the current study are available from the corresponding author on reasonable request.

\section{References}

Bonacci O, Pipan T, Culver DC (2009) A framework for karst ecohydrology Environm ental Geology 56:891-900 doi:https://10.1007/s00254-008-1189-0

Brantley SL et al. (2017) Reviews and syntheses: on the roles trees play in building an d plumbing the critical zone Biogeosciences 14 doi:https://10.5194/bg-14-5115-2017

Canton Y et al. (2016) Vertical and lateral soil moisture patterns on a Mediterranean k arst hillslope Journal of Hydrology 64:209-217 doi:https://10.1515/johh-2016-0030

Chen H-S, Fu W, Wang K-L, Zhang J-G, Zhang W (2006) Dynamic Change of Soil W ater in Peak-Cluster Depression Areas of Karst Mountainous Region in Northwest Guangxi Journal of Soil and Water Conservation 20:136-139 doi:https://10.13870/j.cnki.stbcxb.2006.0 
4.033 (In Chinese)

Chen L, Huang Z, Gong J, Fu B, Huang Y (2007) The effect of land cover/vegetation on soil water dynamic in the hilly area of the loess plateau, China Catena 70:200-208 doi:h ttps://10.1016/j.catena.2006.08.007

Chen Q, Xiong K, Zhou M, Xu F (2018) Characteristics of soil and water loss in diffe rent rocky desertification areas in Guanling county Research of Soil and Water Conservation 25 doi:https://10.13869/j.cnki.rswc.2018.05.003 (In Chinese)

Dai Q, Peng X, Yang Z, Zhao L (2017) Runoff and erosion processes on bare slopes i $\mathrm{n}$ the Karst Rocky Desertification Area CATENA 152:218-226 doi:https://doi.org/10.1016/j.c atena.2017.01.013

Daly E, Porporato A (2005) A review of soil moisture dynamics: from rainfall infiltrati on to ecosystem response Environmental engineering science 22:9-24 doi:https://10.1089/ees. 2005.22.9

Ding Y, Nie Y, Chen H, Wang K, Querejeta JI (2020) Water uptake depth is coordinate $\mathrm{d}$ with leaf water potential, water-use efficiency and drought vulnerability in karst vegetatio n New Phytologist doi:https://doi.org/10.1111/nph.16971

Fu T, Chen H, Fu Z, Wang K (2016a) Surface soil water content and its controlling fa ctors in a small karst catchment Environmental Earth Sciences 75:1406 doi:https://10.1007/s $\underline{12665-016-6222-0}$

Fu T, Chen H, Wang K (2016b) Structure and water storage capacity of a small karst a quifer based on stream discharge in southwest China Journal of Hydrology 534:50-62 doi:ht tps://doi.org/10.1016/j.jhydrol.2015.12.042

Gao Y, Liu H, Wu H, Alamus (2018) Seasonal changes in soil water repellency of diff erent land use types in Inner Mongolia grassland Soil and Tillage Research 177:37-44 doi:ht tps://doi.org/10.1016/j.still.2017.11.011

Gehrels J, Peeters J, De Vries J, Dekkers M (1998) The mechanism of soil water move ment as inferred from 180 stable isotope studies Hydrological sciences journal 43:579-594 doi:https://10.1080/02626669809492154

Guber A, Gish T, Pachepsky Y, van Genuchten MT, Daughtry C, Nicholson T, Cady R (2008) Temporal stability in soil water content patterns across agricultural fields Catena 73: 125-133 doi:https://10.1016/j.catena.2007.09.010

Guo X, Gong X, Tang Q, Chen C, Jiang G, Li X, Zou Y (2016) The response process es of moisture at soil profile to precipitation in typical karst hillslopes Carsologica Sinica 3 5:629-638 doi:https://10.11932/karst20160604 (In Chinese)

Han W-J, Pan Y-J, Du B (2016) Effects of different rainfall intensity on limestone soil 
water transport of huaxi area in Guiyang city Modern Agricultural Science and Technology 6:189-191+202 (In Chinese)

Hartmann A, Goldscheider N, Wagener T, Lange J, Weiler M (2014) Karst water resou rces in a changing world: Review of hydrological modeling approaches Reviews of Geophy sics 52:218-242 doi:https://10.1002/2013RG000443

Jing J, Liu Z, Li Y, Wang J, Luo D, Cai L (2020) Vegetation Types Affect Responsive Change in Soil Moisture to Rainfall in under Karst Rocky Desertification Control Areas Jou rnal of Irrigation and Drainage 39:100-109 doi:https://10.13522/j.cnki.ggps.2019137

Laio F, Porporato A, Ridolfi L, Rodriguez-Iturbe I (2001) Plants in water-controlled ec osystems: active role in hydrologic processes and response to water stress: II. Probabilistic s oil moisture dynamics Advances in water resources 24:707-723 doi:https://10.1016/s0309-17 $\underline{08(01) 00005-7}$

Li X-Y, Zhang S-Y, Peng H-Y, Hu X, Ma Y-J (2013) Soil water and temperature dyna mics in shrub-encroached grasslands and climatic implications: Results from Inner Mongolia steppe ecosystem of north China Agricultural and Forest Meteorology 171-172:20-30 doi:ht tps://doi.org/10.1016/j.agrformet.2012.11.001

Li X, Li Y, Chen A, Gao M, Slette IJ, Piao S (2019) The impact of the 2009/2010 dro ught on vegetation growth and terrestrial carbon balance in Southwest China Agricultural an d Forest Meteorology 269:239-248 doi:https://10.1016/j.agrformet.2019.01.036

Li Z, Xu X, Zhang Y, Wang K (2020) Fingerprinting sediment sources in a typical kar st catchment of southwest China International Soil and Water Conservation Research 8:277285 doi:https://doi.org/10.1016/j.iswcr.2020.06.005

Liu B, Mu B, Gu X-P (2013) Vertical variability of soil moisture under different precip itation conditions in Guizhou karst areas Guangdong Agricultural Sciences 40:46-49 doi:http s://10.16768/j.issn.1004-874x.2013.02.031 (In Chinese)

Liu H, Jiang T, Liu H, Xiao H, Xia J (2005) Impact of land use on spatio-temporal va riation of soil moisture of sloping upland in karst mountainous area Acta Pedologica Sinica 42 (In Chinese)

Llorens P, Domingo F (2007) Rainfall partitioning by vegetation under Mediterranean c onditions. A review of studies in Europe Journal of hydrology 335:37-54 doi:https:/10.1016/ j.jhydrol.2006.10.032

Lozano-Parra J, Schnabel S, Ceballos-Barbancho A (2015) The role of vegetation cover $\mathrm{s}$ on soil wetting processes at rainfall event scale in scattered tree woodland of Mediterrane an climate Journal of Hydrology 529:951-961 doi:https://doi.org/10.1016/j.jhydrol.2015.09.01 $\underline{8}$ 
Mei X-m, Ma L, Zhu Q-k, Wang S, Zhang D, Wang Y (2018) Responses of soil moist ure to vegetation restoration type and slope length on the loess hillslope Journal of Mountai n Science 15:548-562 doi:https://10.1007/s11629-017-4415-y

Rivera D, Lillo M, Granda S, assessment (2014) Representative locations from time ser ies of soil water content using time stability and wavelet analysis Environmental Monitoring 186:9075-9087 doi:https://10.1007/s10661-014-4067-0

Sohrt J, Ries F, Sauter M, Lange J (2014) Significance of preferential flow at the rock soil interface in a semi-arid karst environment CATENA 123:1-10 doi:https://doi.org/10.1016 /j.catena.2014.07.003

Su B, Shangguan Z (2019) Decline in soil moisture due to vegetation restoration on th e Loess Plateau of China Land Degradation Development 30:290-299 doi:https://10.1002/ldr. $\underline{3223}$

Sun F, Lü Y, Wang J, Hu J, Fu B (2015) Soil moisture dynamics of typical ecosystems in response to precipitation: A monitoring-based analysis of hydrological service in the Qili an Mountains CATENA 129:63-75 doi:https://doi.org/10.1016/j.catena.2015.03.001

Tang M, Zhao X, Gao X, Zhang C, Wu P (2019) Land Use Affects Soil Moisture Res ponse to Dramatic Short-term Rainfall Events in a Hillslope Catchment of the Chinese Loes s Plateau Agronomy Journal 111:1506-1515 doi:https://10.2134/agronj2018.06.0405

Wang S, Fu B, Gao G, Liu Y, Zhou J (2013) Responses of soil moisture in different la nd cover types to rainfall events in a re-vegetation catchment area of the Loess Plateau, Chi na CATENA 101:122-128 doi:https://doi.org/10.1016/j.catena.2012.10.006

Wang X-P, Cui Y, Pan Y-X, Li X-R, Yu Z, Young MH (2008) Effects of rainfall chara cteristics on infiltration and redistribution patterns in revegetation-stabilized desert ecosystem s Journal of Hydrology 358:134-143 doi:https://doi.org/10.1016/j.jhydrol.2008.06.002

Yang J, Chen H, Nie Y, Wang K (2019) Dynamic variations in profile soil water on ka rst hillslopes in Southwest China CATENA 172:655-663 doi:https://doi.org/10.1016/j.catena.2 $\underline{018.09 .032}$

Yang L, Zhang HD, Chen LD (2018) Identification on threshold and efficiency of rainf all replenishment to soil water in semi-arid loess hilly areas Science China Earth Sciences 6 1:292-301 doi:https://10.1007/s11430-017-9140-0 (In Chinese)

Yang S-T, Wang Y-J, Wen Z-Q, Lu T (2007) Research on Soil Moisture in the Typical Shrub-grass Zone in Karst Regions Bulletin of Soil and Water Conservation 27 doi:https://1 0.13961/j.cnki.stbctb.2007.04.030 (In Chinese)

Yu X, Huang Y, Li E, Li X, Guo W (2018) Effects of rainfall and vegetation to soil w ater input and output processes in the Mu Us Sandy Land, northwest China CATENA 161:9 
6-103 doi:https://doi.org/10.1016/j.catena.2017.10.023

Zhang C, Chen H-S, Nie Y-P, Zhang W, Feng T, Wang K-L (2013) Dynamics of soil p rofile water content in peak-cluster depression areas in karst region Chinese Journal of EcoAgriculture 21:1225-1232 doi:https://10.3724/SP.J.1011.2013.01225 (In Chinese)

Zhang D-H, Li X-R, Zhang F, Zhang Z-S, Chen Y-L (2016) Effects of rainfall intensity and intermittency on woody vegetation cover and deep soil moisture in dryland ecosystems Journal of Hydrology 543:270-282 doi:https:// 10.1016/j.jhydrol.2016.10.003

Zhang L, Xiao J, Li J, Wang K, Lei L, Guo H (2012) The 2010 spring drought reduce d primary productivity in southwestern China Environmental Research Letters 7:045706 doi: https://10.1088/1748-9326/7/4/045706

Zhang Y-f, Wang X-p, Hu R, Pan Y-x, Paradeloc M (2015) Rainfall partitioning into th roughfall, stemflow and interception loss by two xerophytic shrubs within a rain-fed re-vege tated desert ecosystem, northwestern China Journal of Hydrology 527:1084-1095 doi:https:// 10.1016/j.jhydrol.2015.05.060

Zhao Z, Shen Y, Wang Q, Jiang R (2020) The temporal stability of soil moisture spati al pattern and its influencing factors in rocky environments Catena 187:104418 doi:https://1 0.1016/j.catena.2019.104418

Zhou Q, Yan H, Ma L, Cai M, Dai L (2016) Distribution characteristics of rainfall inte rception of coniferous forest in Karst area Ecological Science 35:140-145 doi:https://10.1410 8/j.cnki.1008-8873.2016.06.019 (In Chinese)

Zhu Q, Nie X, Zhou X, Liao K, Li H (2014) Soil moisture response to rainfall at diffe rent topographic positions along a mixed land-use hillslope CATENA 119:61-70 doi:https://d oi.org/10.1016/j.catena.2014.03.010 


\section{Funding}

This work were supported by the Joint Fund of the National Natural Science Foundation of China and th e Karst Science Research Center of Guizhou province [grant number U1812401]; the National Science Fo undation of China [grant number 41761003], the Basic Research Program of Guizhou Province [grant nu mber Qiankehe Jichu [2019]1433 \& [2017]1131].

\section{Author information}

\section{Affiliations}

School of Geography and Environmental Science, Guizhou Normal University, 550001 Guiyang

, People's Republic of China

Weihong Yan, Qiuwen Zhou, Dawei Peng, Xiaocha Wei, Xin Tang, Ershuang Yuan, Yalin Wang,

Chunmao Shi

\section{Contributions}

W.Y. and Q.Z. conceived and wrote the manuscript; D.P. and X.W. polished the language of the manuscri pt; X.T., E.Y., Y.W. and C.S. was involved in the experimental assays.

\section{Corresponding author}

Correspondence to Qiuwen Zhou. 


\section{Ethics declarations}

\section{Competing Interest}

The authors declare no conflict of interest.

\section{Ethical approval}

Not applicable.

\section{Consent to Participate}

Not applicable.

\section{Consent to publish}

Not applicable. 


\section{Figures}

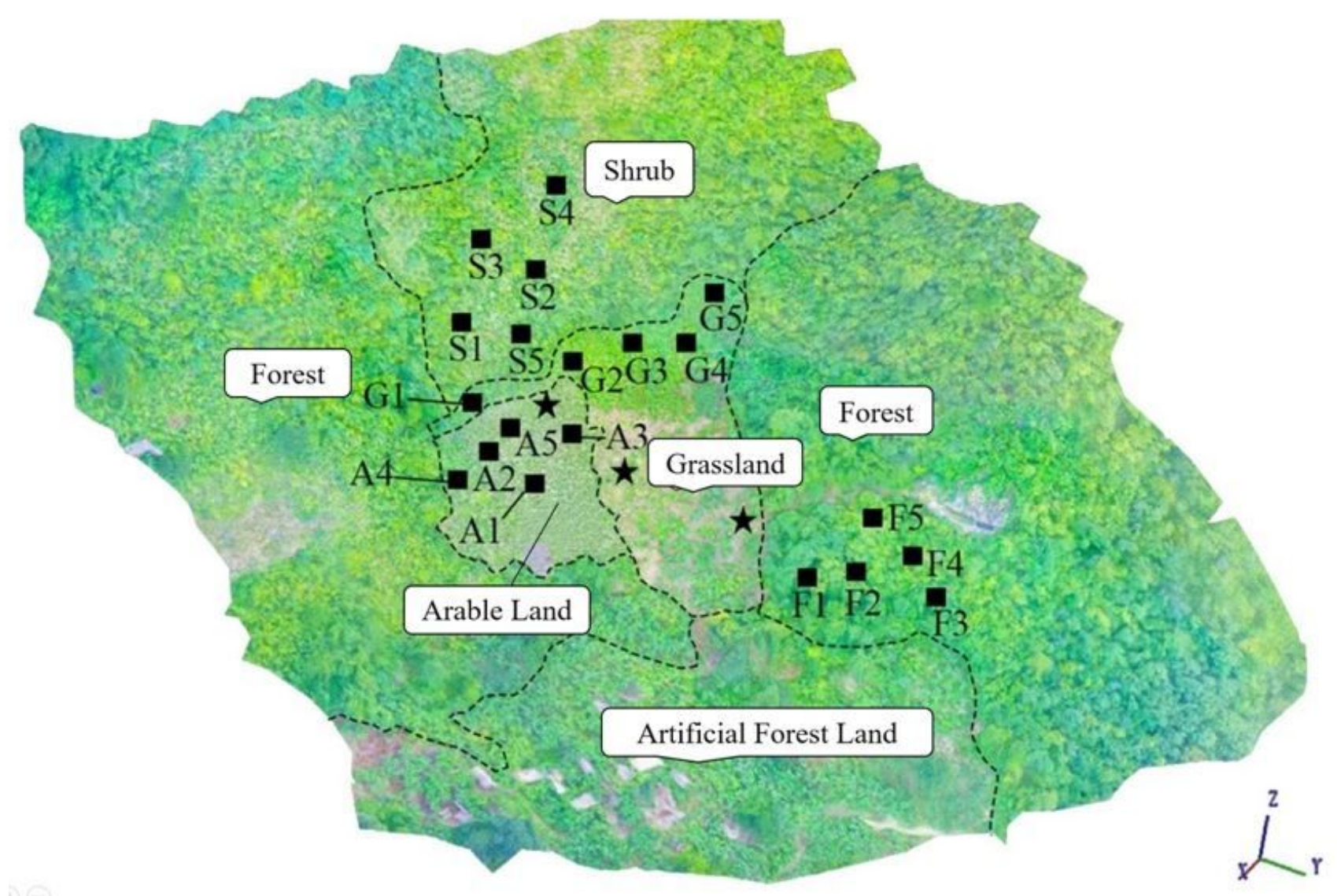

\section{Figure 1}

Distribution map of the sample plots. A1-A5 indicate arable land plots; $\mathrm{G} 1-\mathrm{G} 5$ indicate grassland plots; $\mathrm{S} 1-\mathrm{S} 5$ indicate shrub plots; and F1-F5 indicate forest plots. The $₫ \mathrm{~s}$ indicate rain gauges. Note: The designations employed and the presentation of the material on this map do not imply the expression of any opinion whatsoever on the part of Research Square concerning the legal status of any country, territory, city or area or of its authorities, or concerning the delimitation of its frontiers or boundaries. This map has been provided by the authors. 


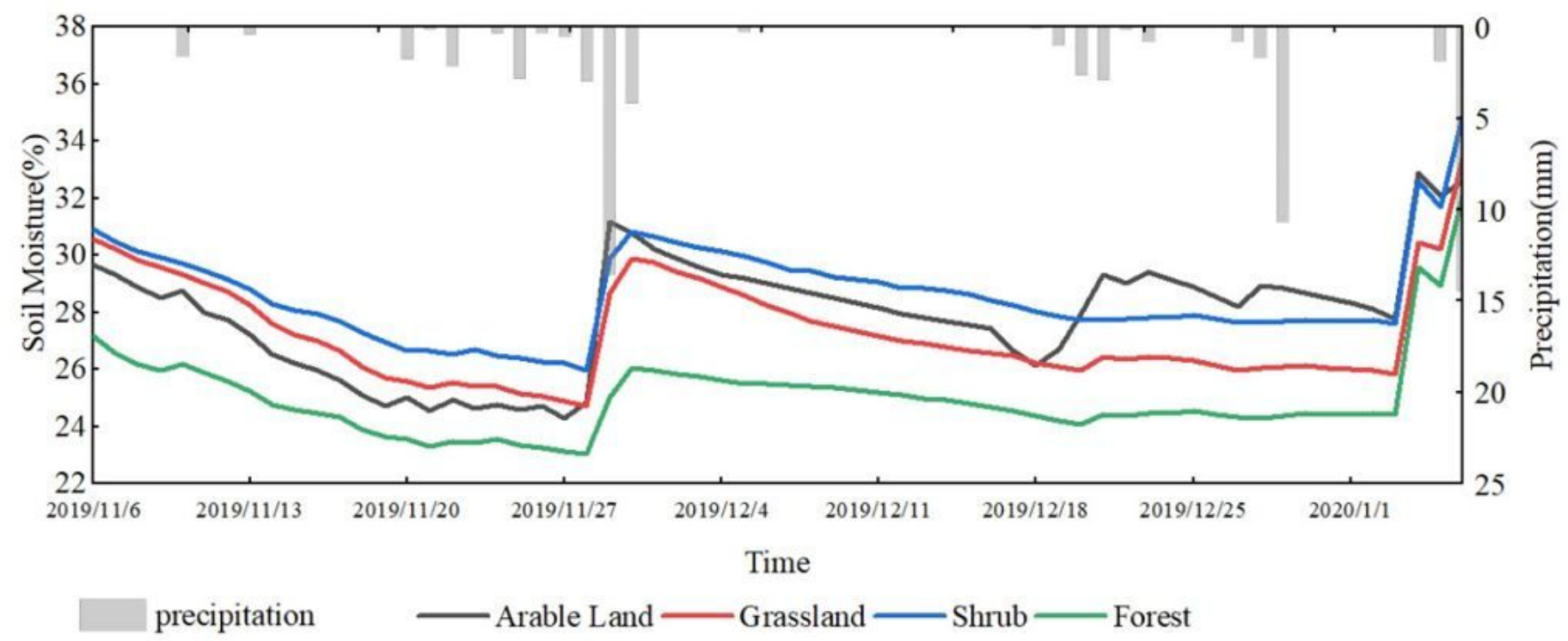

Figure 2

Dynamic changes in the mean soil moisture content and precipitation distribution for the different vegetation types. 

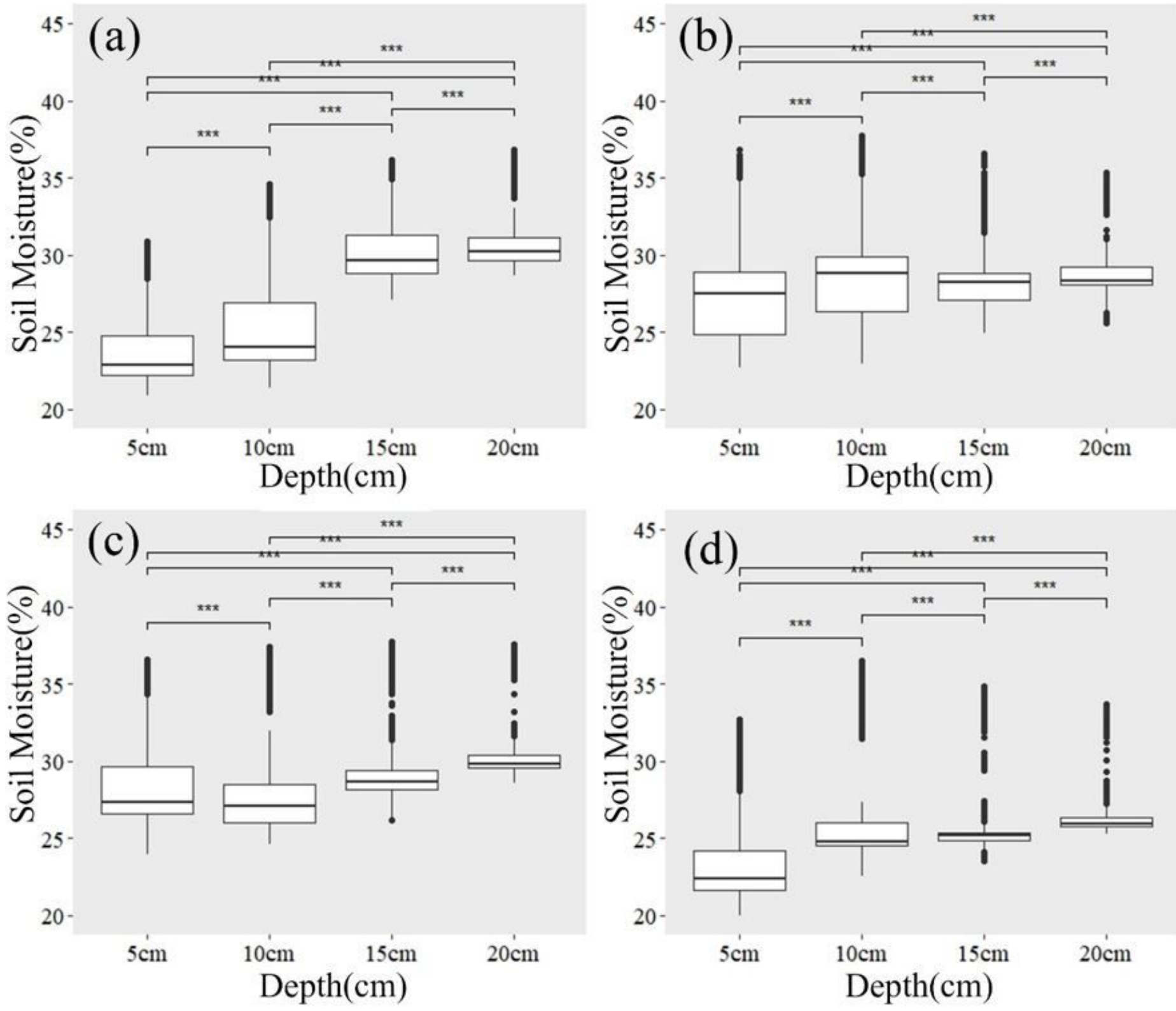

Figure 3

Characteristics of the soil moisture in the different soil layers under the different vegetation types: (a) arable land; (b) grassland; (c) shrub; and (d) forest. 

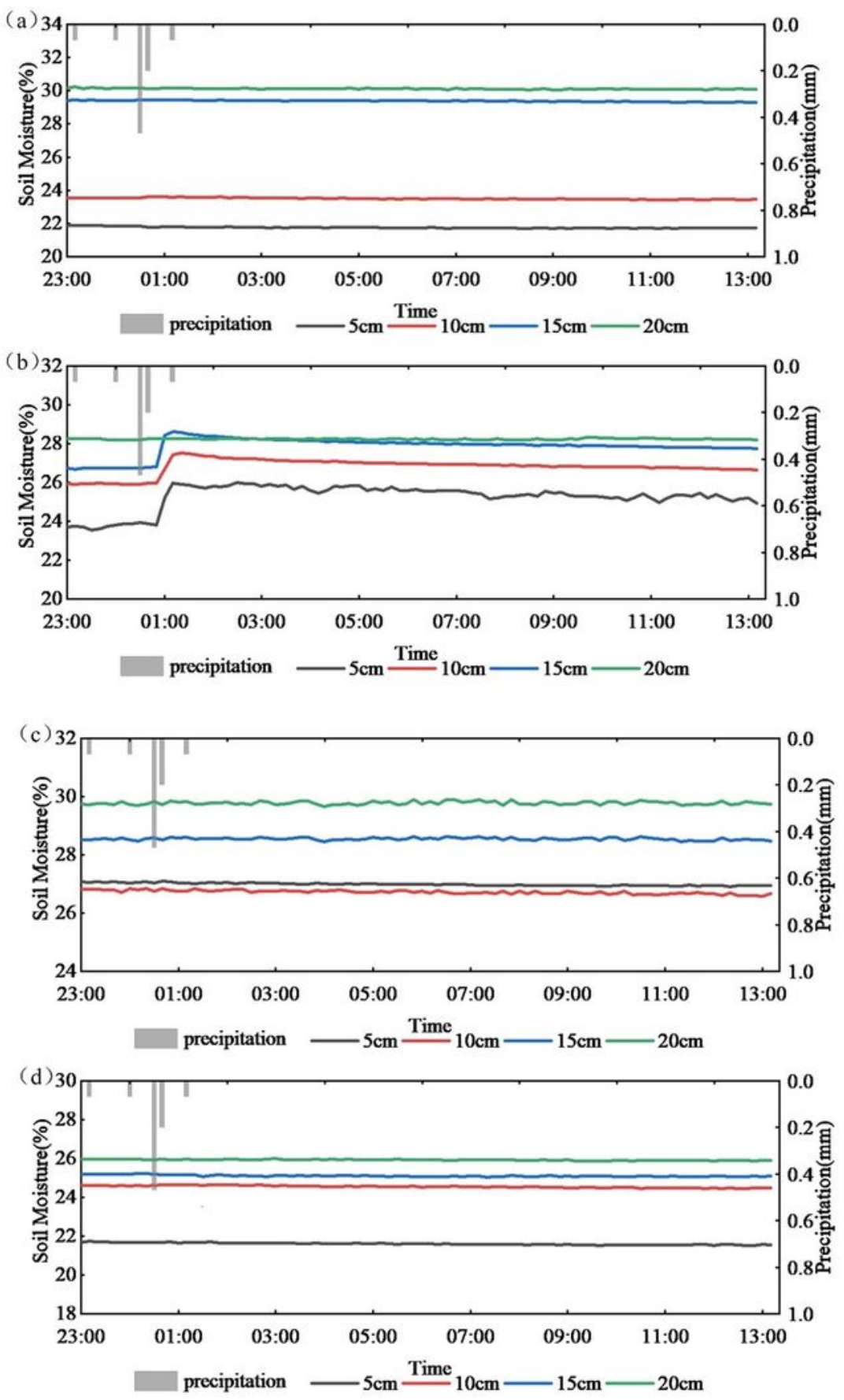

\section{Figure 4}

Responses of soil moisture under the different vegetation types to rainfall: (a) arable land; (b) grassland; (c)shrub; and (d) forest. 


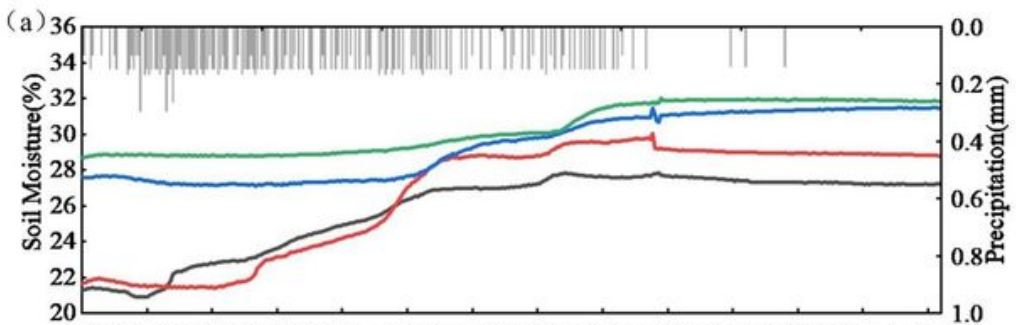

17:50 22:50 03:50 08:50 13:50 18:50 23:50 04:50 09:50 14:50 19:50 00:50 05:50 10:50

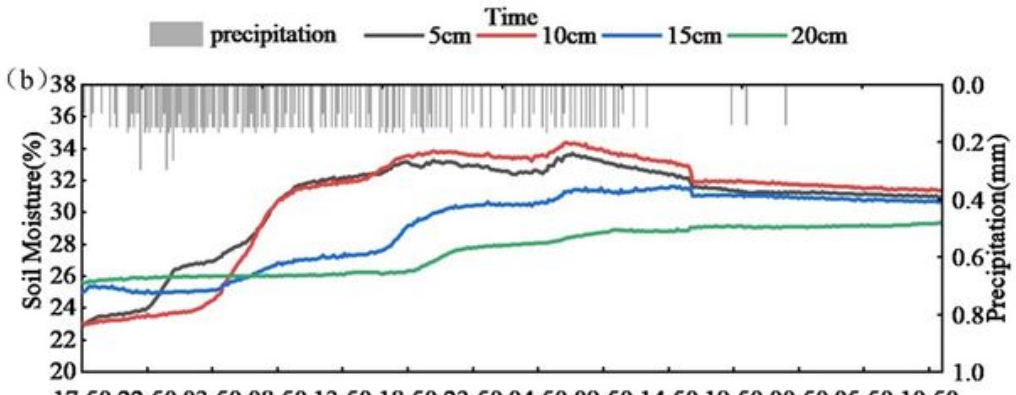

17:50 22:50 03:50 08:50 13:50 18:50 23:50 04:50 09:50 14:50 19:50 00:50 05:50 10:50

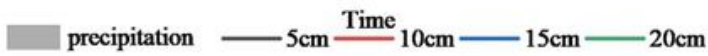

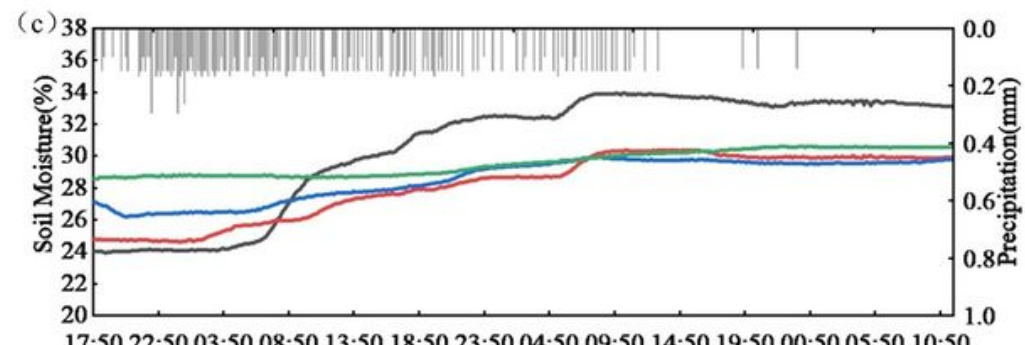

17:50 22:50 03:50 08:50 13:50 18:50 23:50 04:50 09:50 14:50 19:50 00:50 05:50 10:50

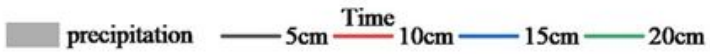

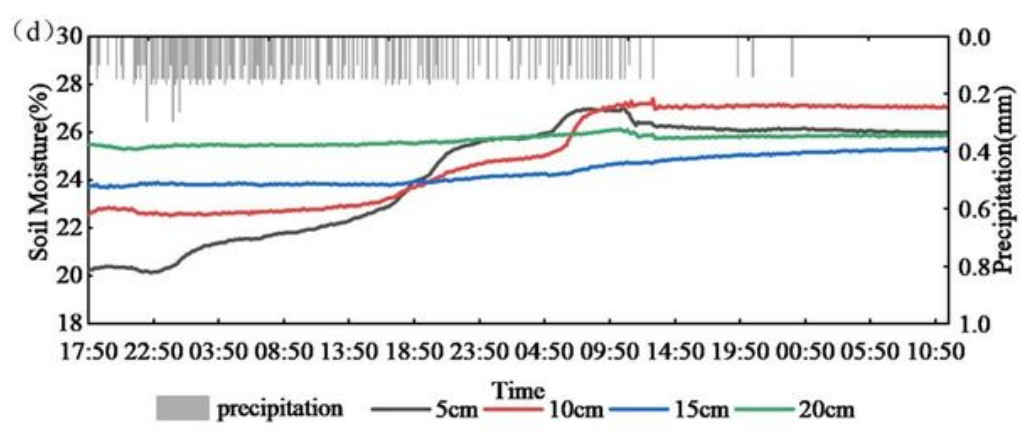

\section{Figure 5}

Responses of soil moisture under the different vegetation types to rainfall: (a) arable land; (b) grassland; (c) shrub; and (d) forest. 

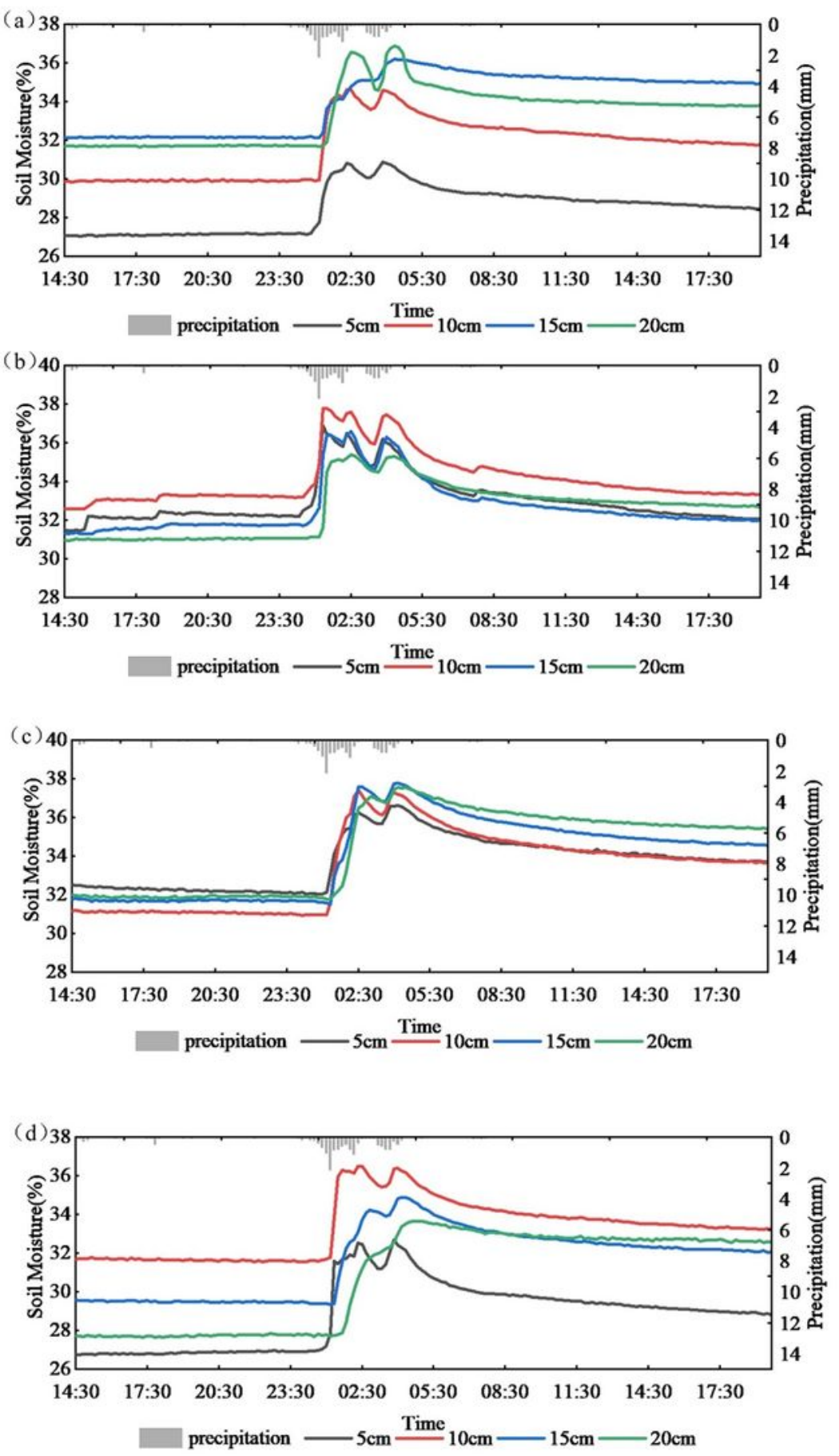

\section{Figure 6}

Responses of soil moisture under the different vegetation types to rainfall: (a) arable land; (b) grassland; (c) shrub; and (d) forest. 

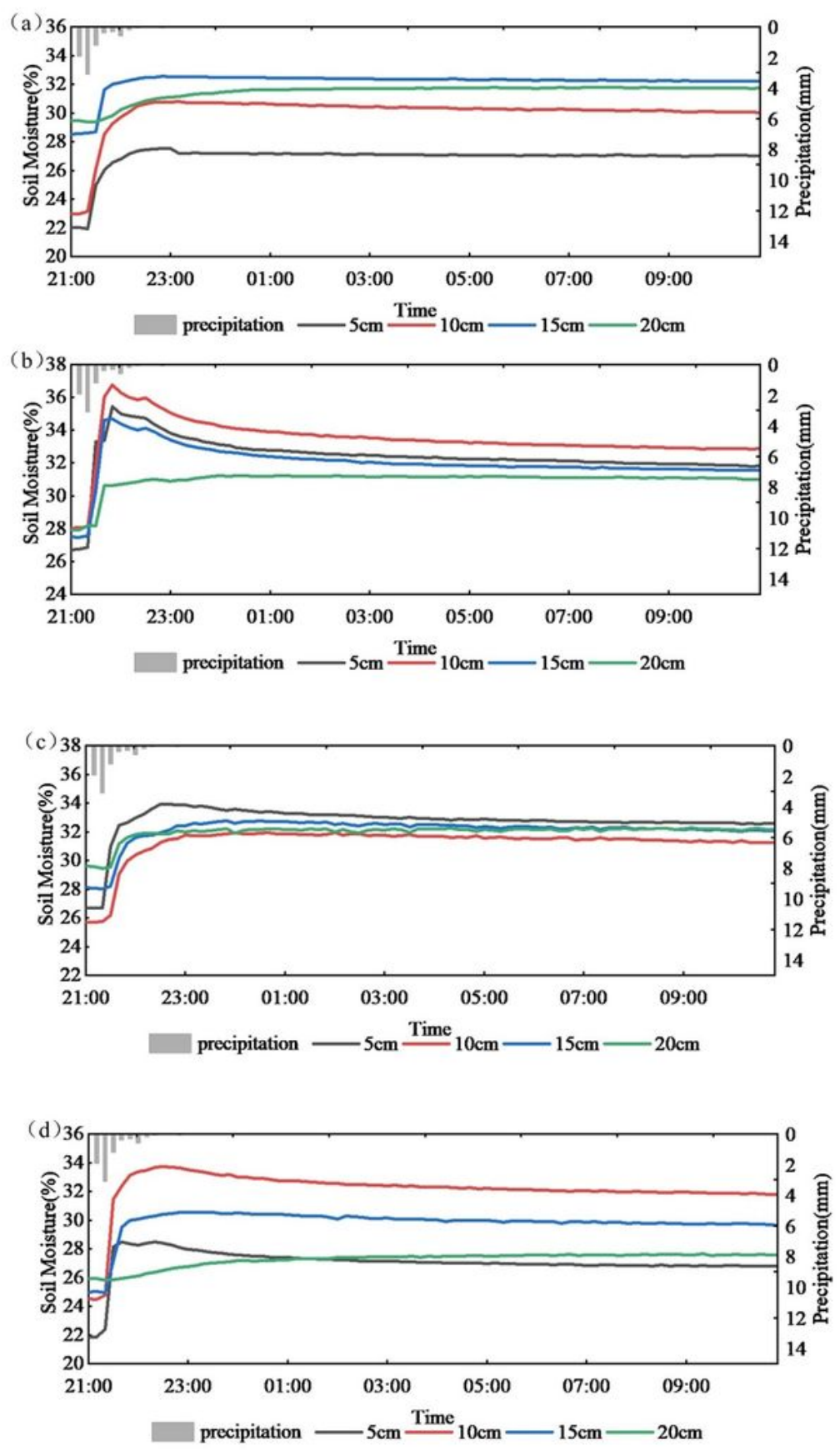

\section{Figure 7}

Responses of soil moisture of different vegetation types to rainfall: (a) arable land; (b) grassland; (c) shrub; and (d) forest. 

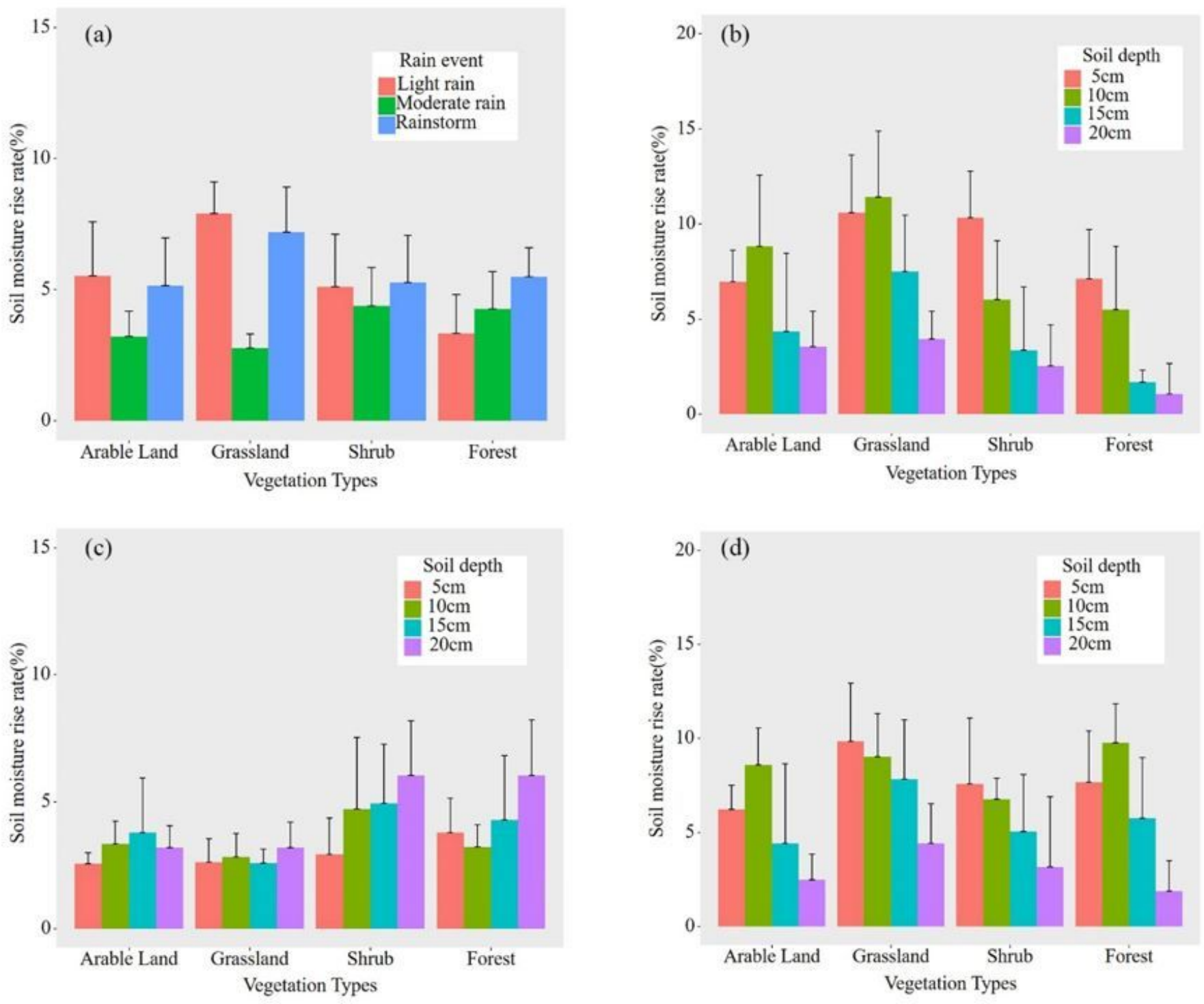

\section{Figure 8}

Statistical graphs of the increase in the soil moisture under the different vegetation types (a) during three different rainfall events; (b) at different depths during a light rainfall event; (c) at different depths during a moderate rainfall event; and (d) at different depths during a rainstorm event. 
20 -

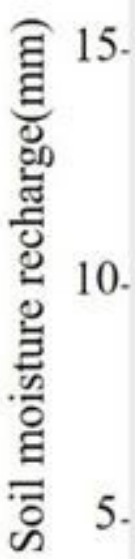

0 .

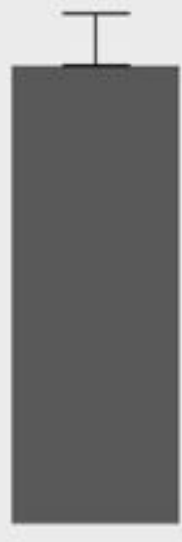

Arable Land

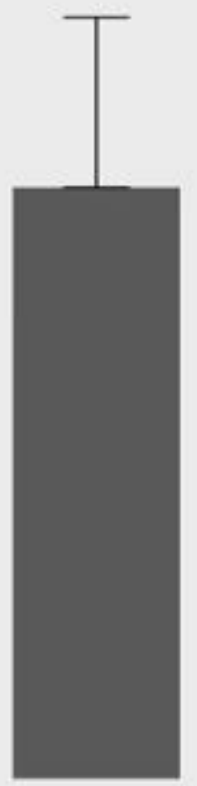

Grassland

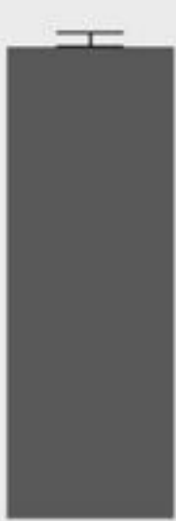

Shrub

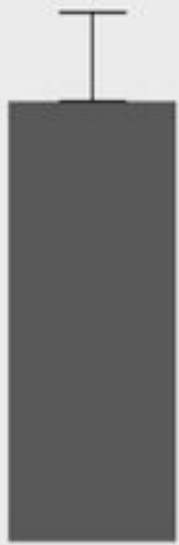

Forest

Vegetation Types

Figure 9

Soil moisture replenishment under the different vegetation types. 
4.

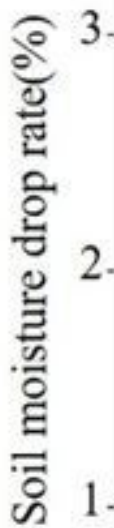

0 .
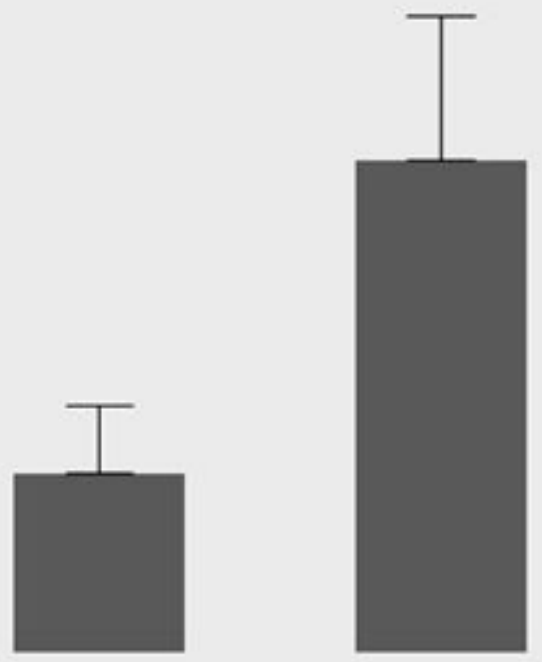

Arable Land

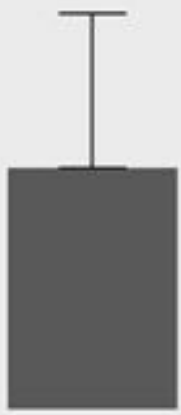

Shrub

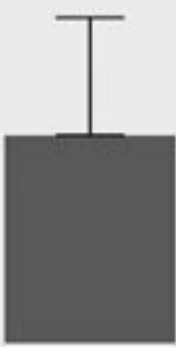

Forest

Vegetation Types

Figure 10

Statistical graph of the decline in soil moisture of different vegetation types 